2G005a ホスファヂジルタールアミンのアマドリ生成物の

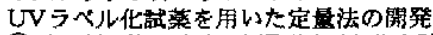

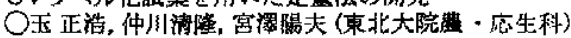

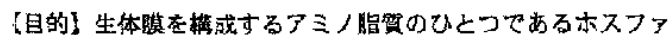
チジルエタノールアミン(PE)は、タンパク留と同搛にアミノカ ルホホニル反态を受け、アマドリ生成物である䀧化ホスファチシ ルエタノールアミン(gPE)を生じるり。是品動物体内で䠑 リン脂㪇のダリケーションによるgPEの生成とその生理作用に 興玶が持たれるが、gPEは特徽的なUV吸取を示さないため。 その生成の実体や存在量は汪と九ど明らかにされていない。そ こでUVラパル化赫菜を用いたgPE定量法の開発を行った。

【方法と結果】PEとグルコースをインキュベートするよ。 gPEが生成することをLC-ESI/TOF MSで礁認した。gPEの生

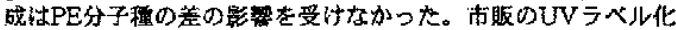

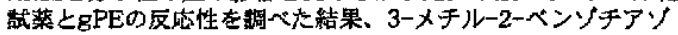
リノンヒドラソン(MBTH)がgPEと最も良く反度し、318 nm に樰大吸取を示すMBTH付加物(MBTH-gPE)を生じることが わかったこの付加物の形成により、UV-HPLC法でgPEがナ

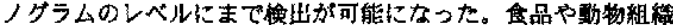
の膜脂留のグリケーションにおけるgPEの頵定が可能になった。 V T. Mlyazawa et al: Blosel. Biotechnot. Biochem., 62, 893 (1998),

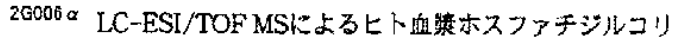
ンヒドロベルオキシドの分析

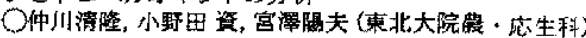

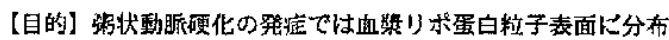
於膜りン脂資の酸化变性が特徽的に見出され、マクロファー 污の泡沫化を䄧発する危険团子のひとつとして重要視されてい

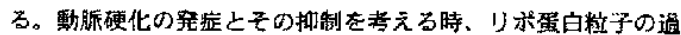
酸化りン脂質の主成分であるホスファチジルコリンヒドロペル オキシド(PCOOH) の生成機㭗の解明が重要である。従来こ の研究はCL-HPLC法で惯討がなされてきたが、ここではLCESI/TOF MSによるPCOOH分子種の分析を行った。

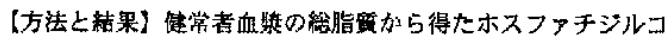
リン画分をLC-ESI/TOF MS (LC: NANOSPACE, Shiseido; MS: Mariner, PerSeptlve Biosystems) K供L、 $\mathrm{PCOOH}$ 分 子種のMSクロマトグラムとMSズベクトルを観測した。健常者 の血留PCOOHの主要な分子種は、1-パルミトイルー2-ヒドロ ペルオキシリノレオイクーホスホリルコリン (16:0-18:2$\mathrm{OOH}-\mathrm{PC}$ )であり、これは中前にCL-HPLC法で分析した血 鋉PCOOHの主要分子種と同一であった。

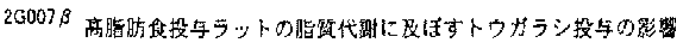

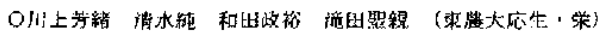

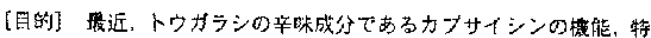

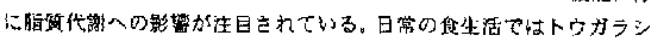

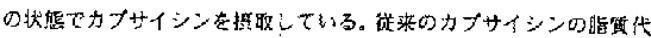

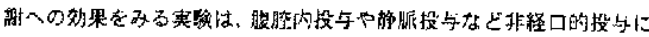

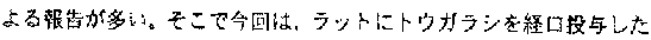

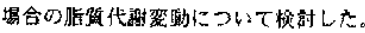

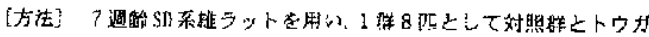

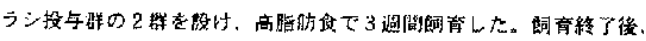

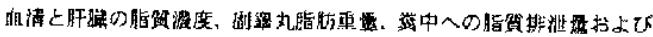
体得肪靽を相定した。

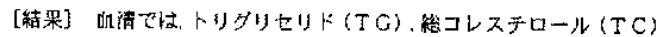

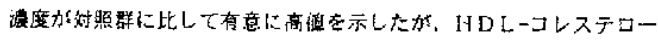

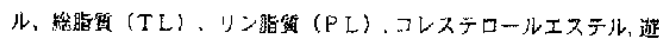

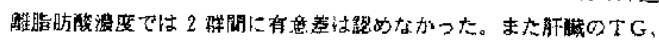

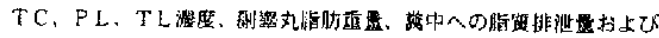

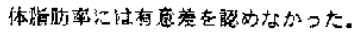

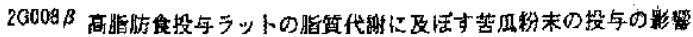

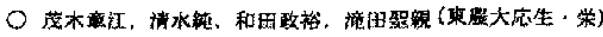

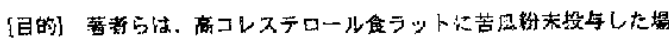

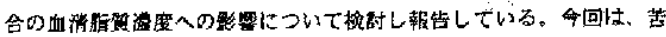

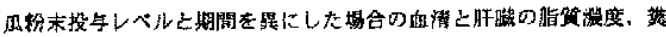

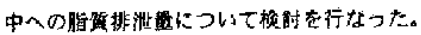

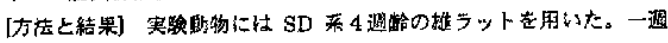

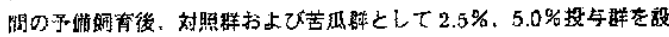

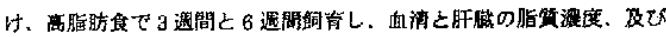

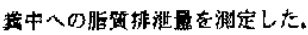

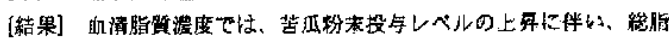

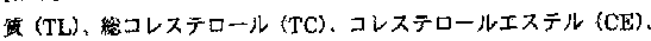

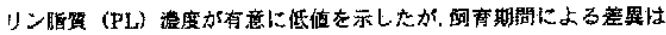

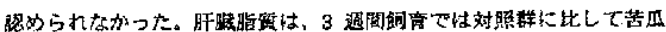

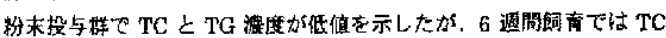

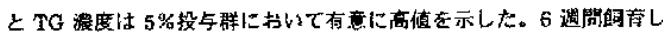

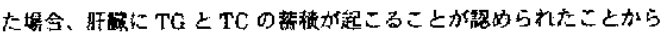
今後は、これらの楼序につに:て括郡したい。

$26009 \alpha$

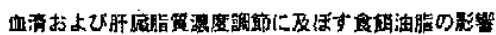

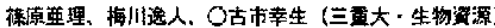

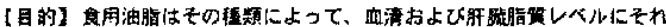

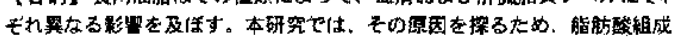

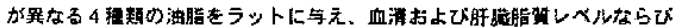

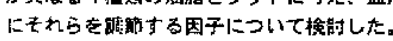

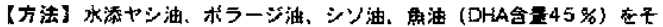

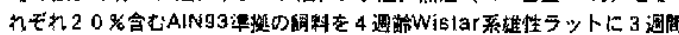

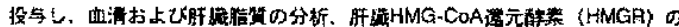

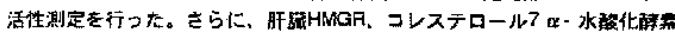

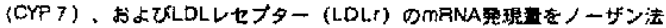
により测った。

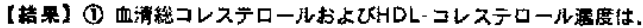

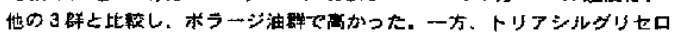
一ル源度は、水添ヤシ油群て高く、シソ油群て抵加った。た、リン脂行

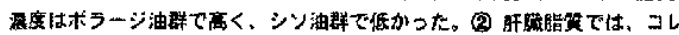
ステロール合贯は、ボラージ油群が水添ヤジ油群むよびシソ油群上り高か

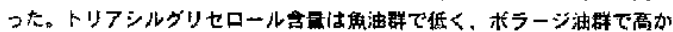

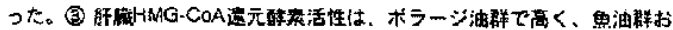

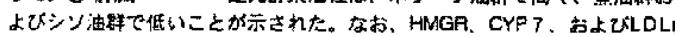
DMPINA热現については将赫中である。

2 CO10B

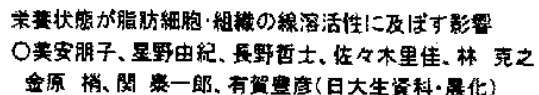

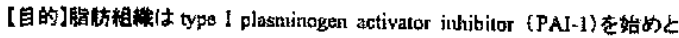

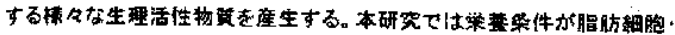

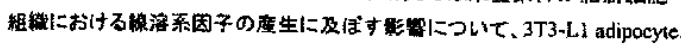

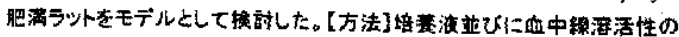

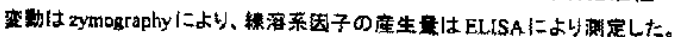

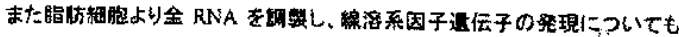

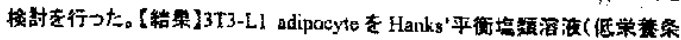

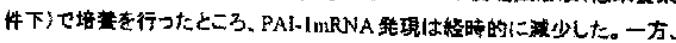

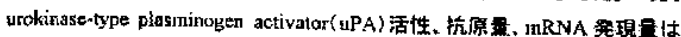

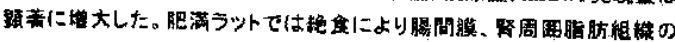

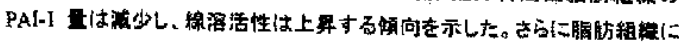

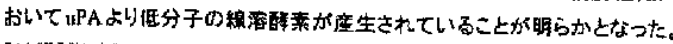

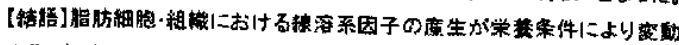
するーとが明らかとなった。 


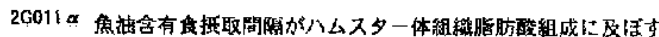
影数

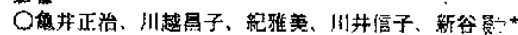

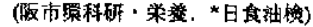

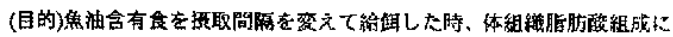
いかなる影謷放胃られるかハムスターを用いて梌驸した。

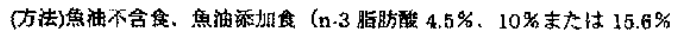

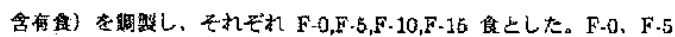

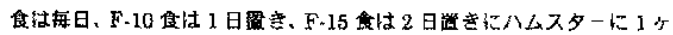

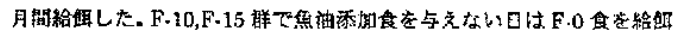

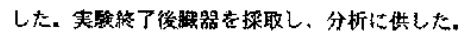

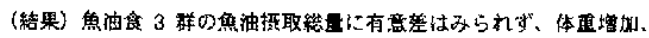

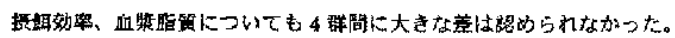

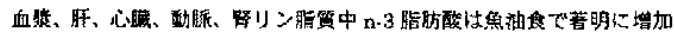

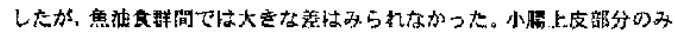

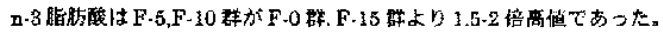

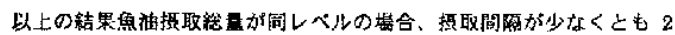

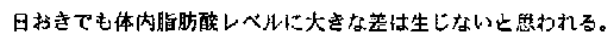

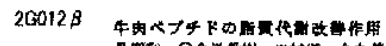

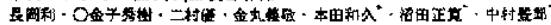

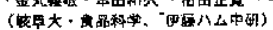

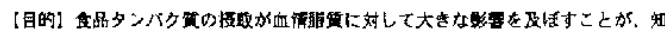

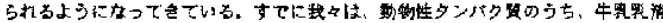

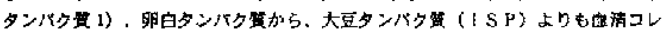

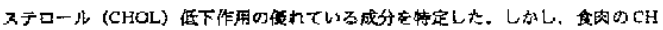

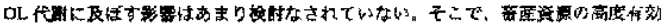

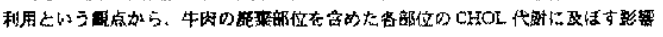

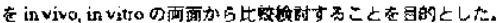

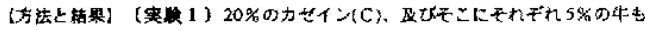

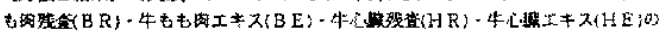

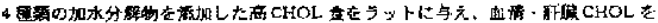

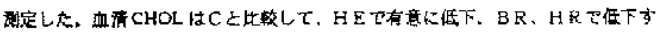

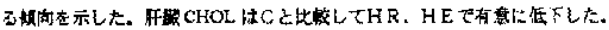

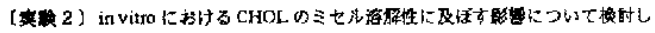

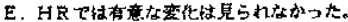

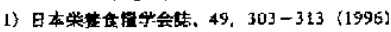

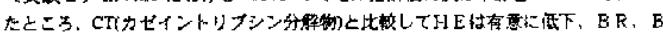

$2 \cot 4 \alpha$

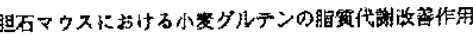

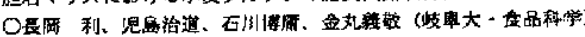

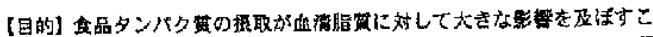

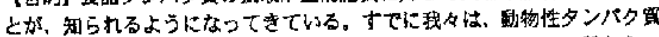

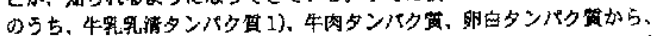
大豆タンバ夕筫 (ISP) 上りも血消コレステロール (CHOL) 低下作用の经

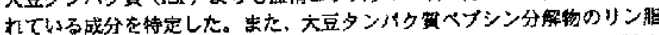

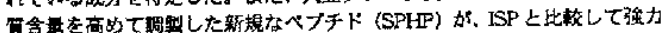

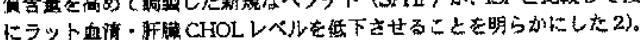

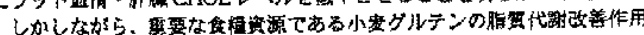

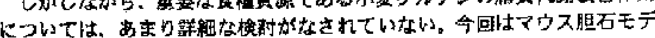

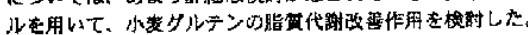

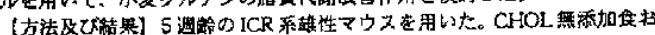
上び、CHOL添加会について、20\%力せイン群（C群）と20\%小娄グルテ

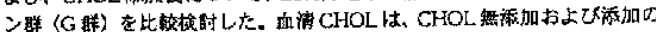

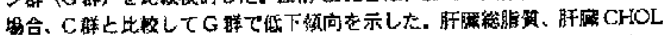

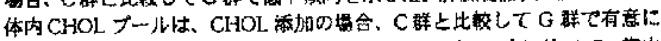

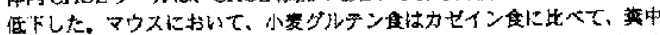

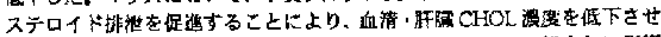

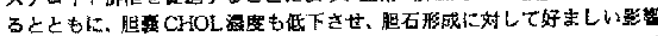

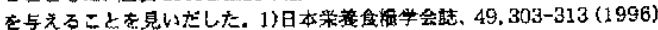
2) J.Nutr. 129, 1725-1730 (1999)

\section{$2 \mathrm{CO} 15 \mathrm{~B}$}

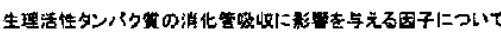

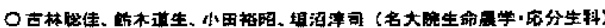

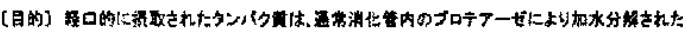

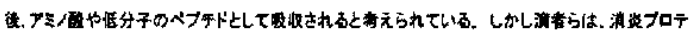

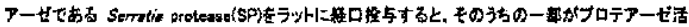

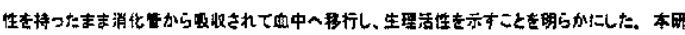

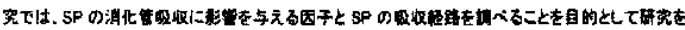
杼主。

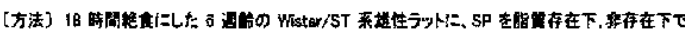

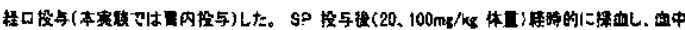

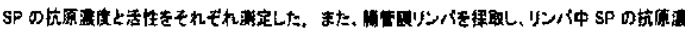
度七活性をもれそれ游定した。

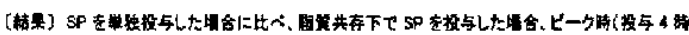

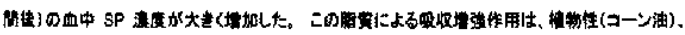

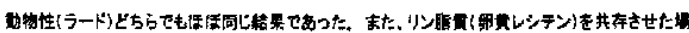

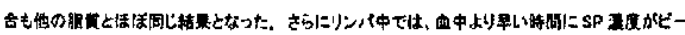

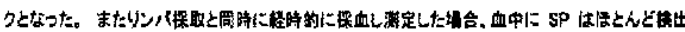

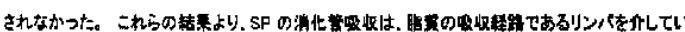

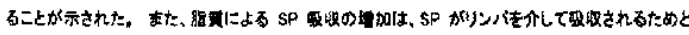
推維された。

$2 \mathrm{G} 016 \alpha$

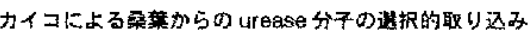

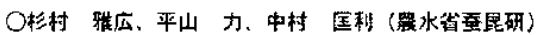

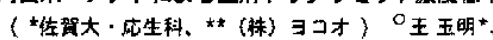

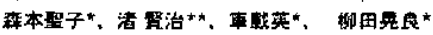

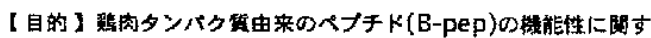

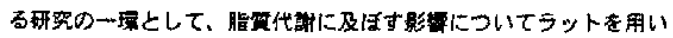
て撸剖した。

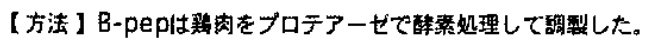

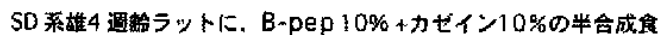

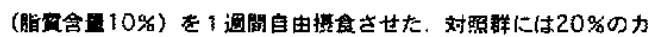

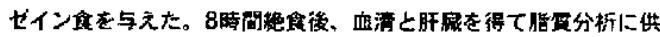
Lた.

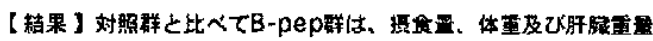

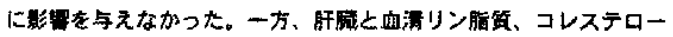

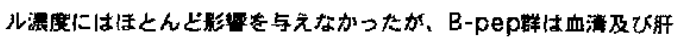

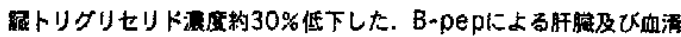

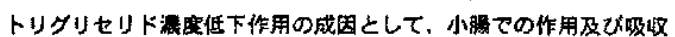

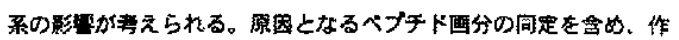
用のメカニスムについて現在援討中である。

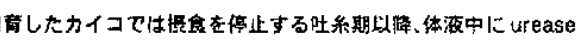

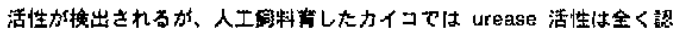

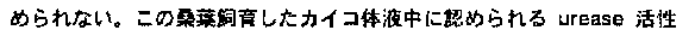

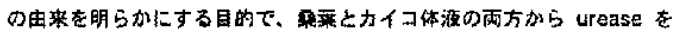

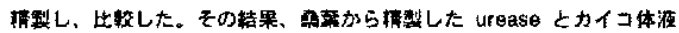

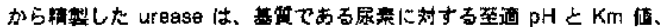
SDSPAGE に上る移期度、抗ナタマメ urease モノクローナル抗体に対

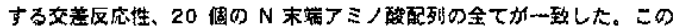

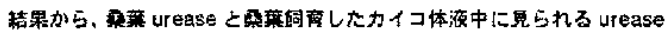

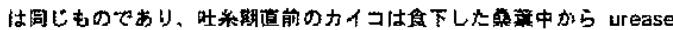
分子を欺り込んでいる束が推察された。

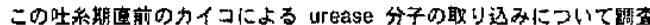

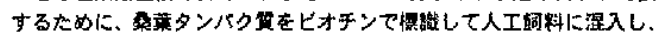

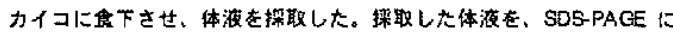

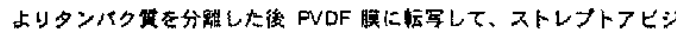

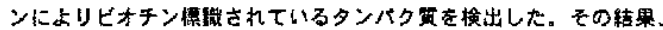

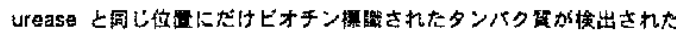

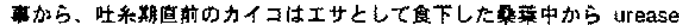
分子だけを䢙报的に取り込九でいる事が示哮された。 
$2 \mathrm{G} 017 \boldsymbol{\beta}$

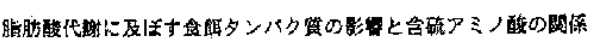

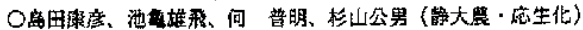

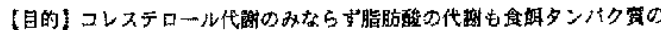

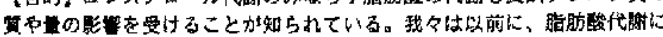

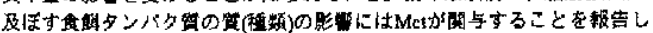

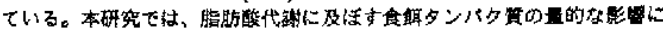

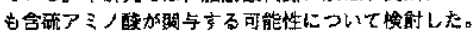

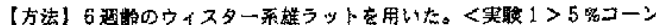

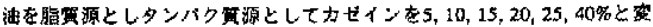

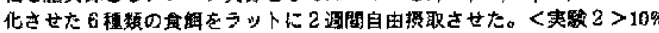
力ぜインとこれに0.43\% Met、0.34\%Cys、3\%Gly、3\%Gly+0.43\% Melを添

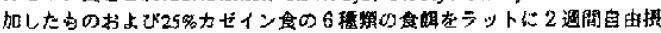

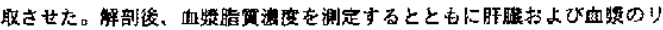

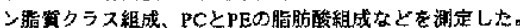

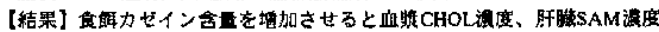

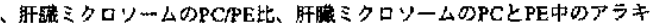

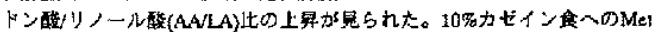

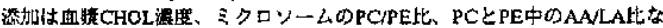

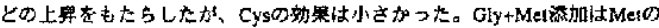

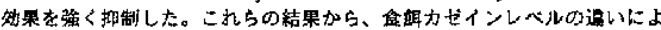

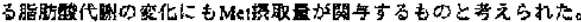

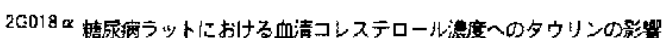

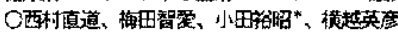

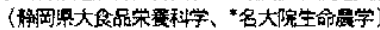

【及的】タウリン(Tau)の作用としてコレステロール(CHOL)低F作用を有するこ とが知られている。我っはこれまでにいくつかの高䎠清 CHDL 条件下における

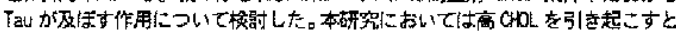

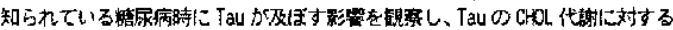
影照志换钨した。

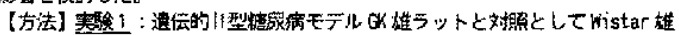

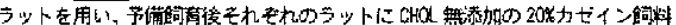

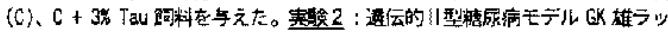

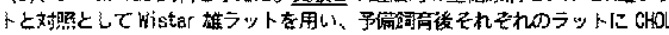

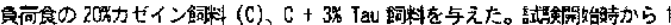

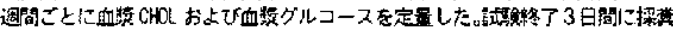

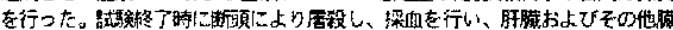

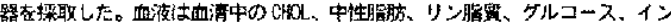

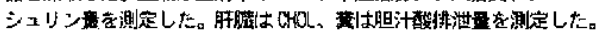

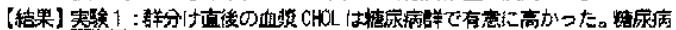

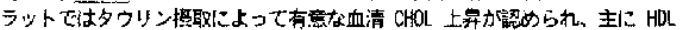

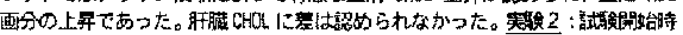

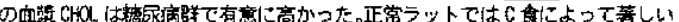

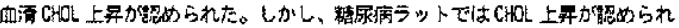

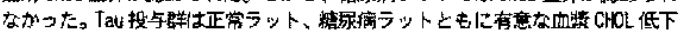

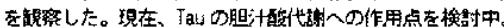

$2 \operatorname{cot9} \beta$

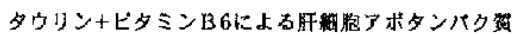

$B_{100}$ 上T G00和㛗下

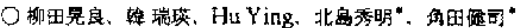

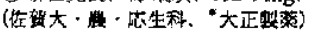

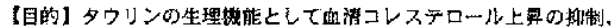

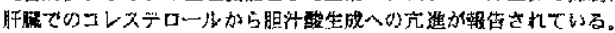

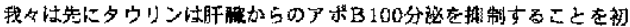
的て見いだした. 本研究で，タウリンとピタミンB6の併用がヒト肝

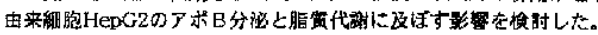

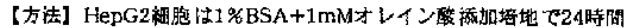

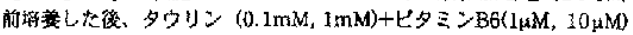

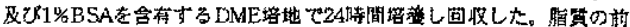

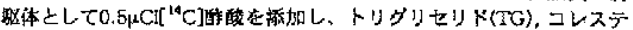

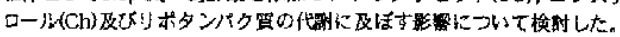

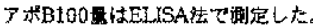

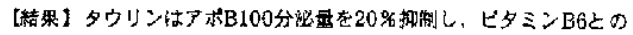

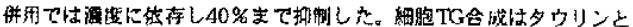

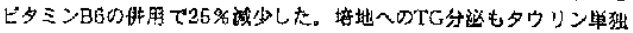

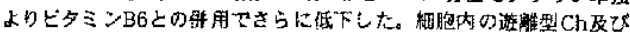
エステル型Chの合成も20\%呫上ど6\%低下した。本研究にお引て，

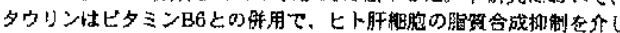
てTGとCh分絓及びアボB100分䟤をさらに低下させることが示された。
260200

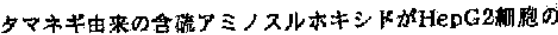

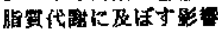

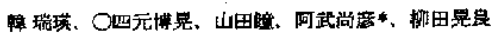

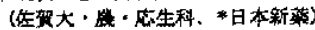

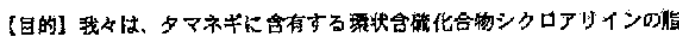

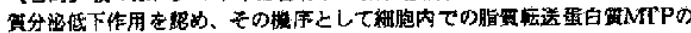

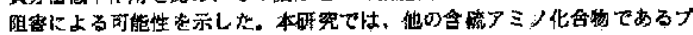
ロピル-L-システインスルホキシF(propyl-Cys-SO)挄よURL-メテオテン

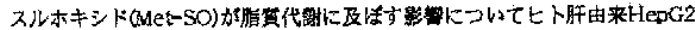
踝胞を用いて模的した。

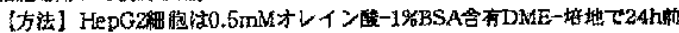

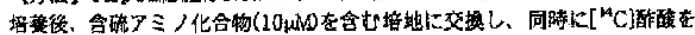

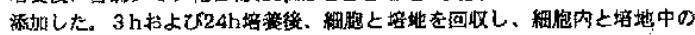
ラヘルされた脂基の放时结括性を測定した。

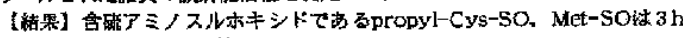

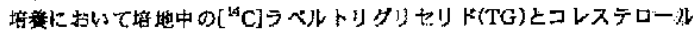

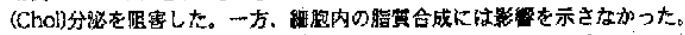

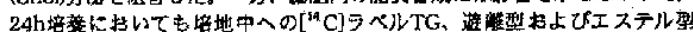

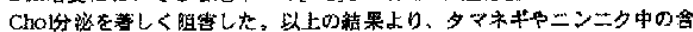

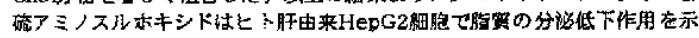
すことを明らかにした。

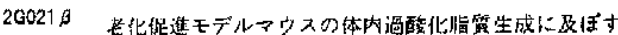

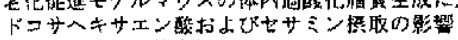

○池田到子、朴曾度信*、山下か心

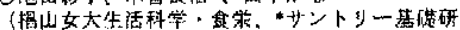

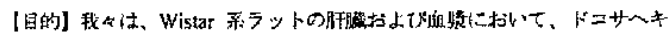

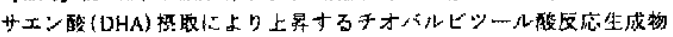

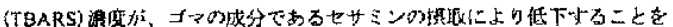

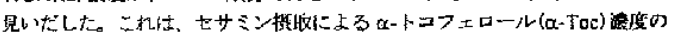

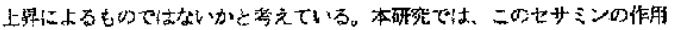

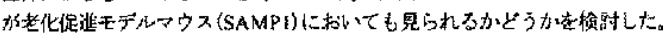

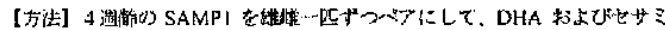

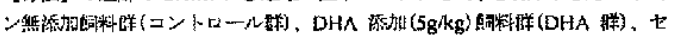

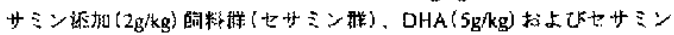

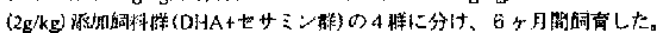

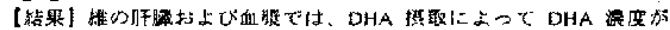

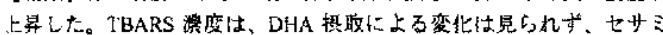

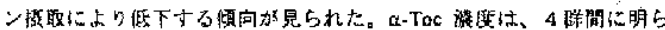

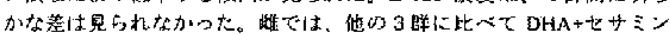

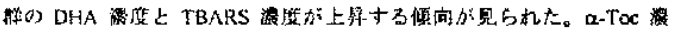

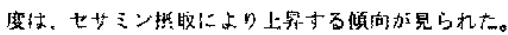

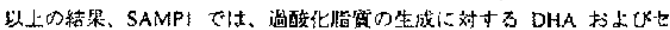

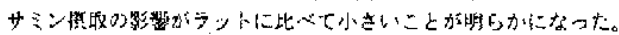

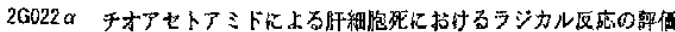

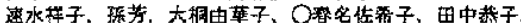

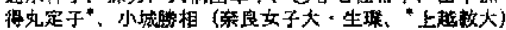

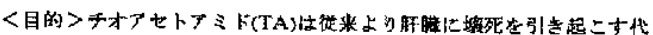

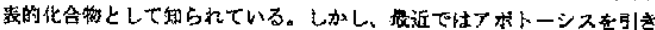

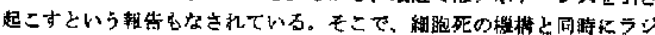

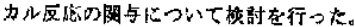

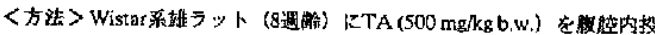

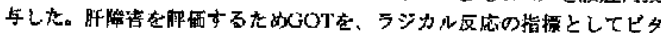

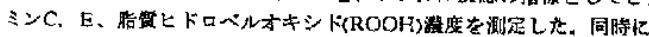

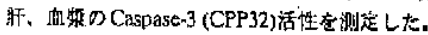

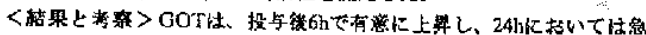

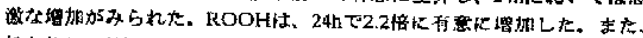

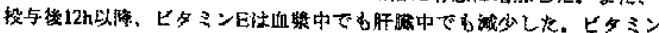

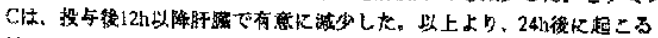

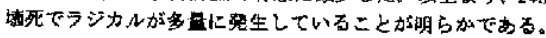

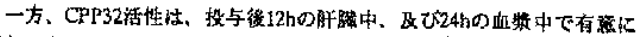

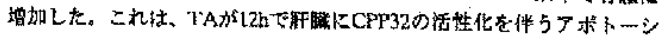

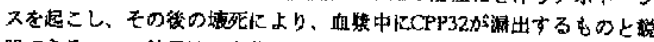

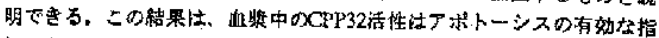
㯊になることを示している。 
200238

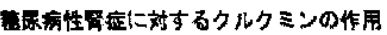

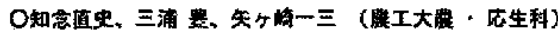

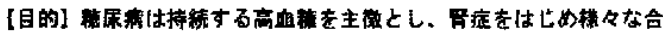

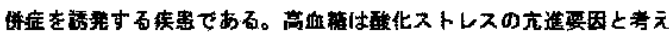

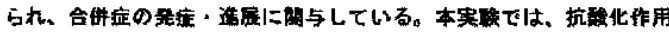
を有するターメリック英色色素成分の一つで苗るクルクミンが、落展

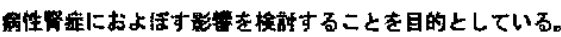

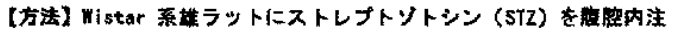

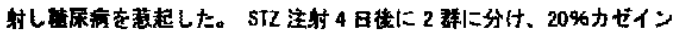

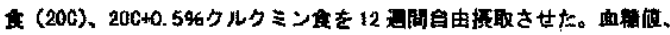

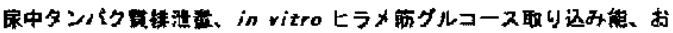

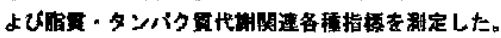

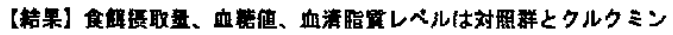

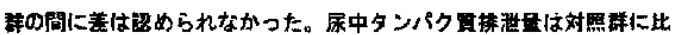
ベクルクミン群で常に侮值を示し、6 および8 清目では有意な低下が

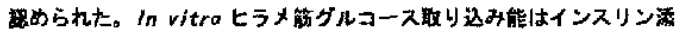
加封に対照群に比ベクルクミン群で有意な上早が瑟められた。これら

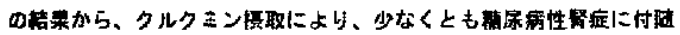
する症状の一部が改帚される可能性が示啅された。

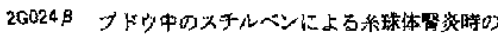

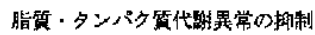

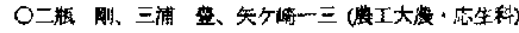

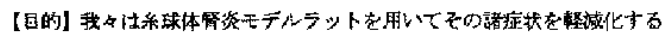

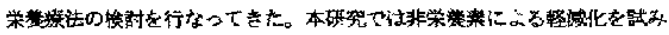

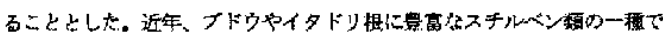

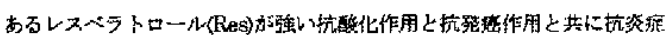

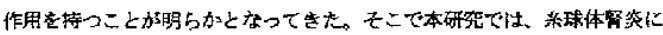
対するRes の作用を明らかにするこ上を目的とする。[方法了Wistar 系

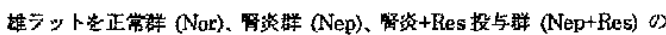

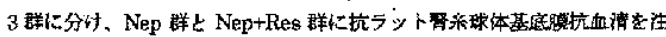

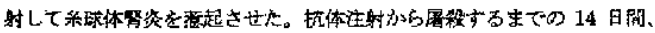

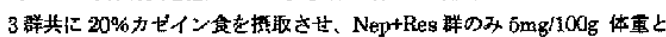

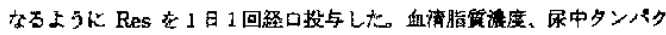

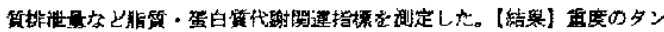

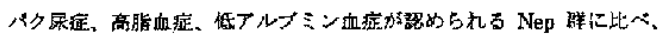

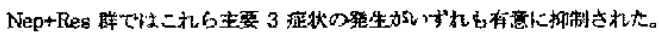

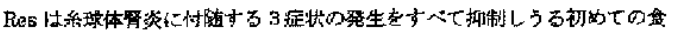
品因子であることが示败された。

$26025 a$

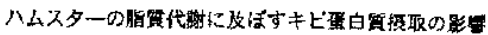

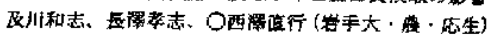

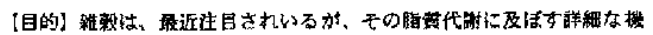

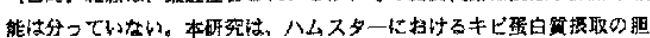

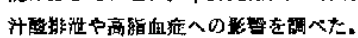

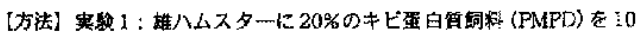

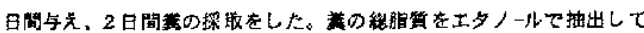

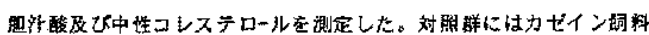

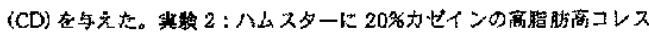

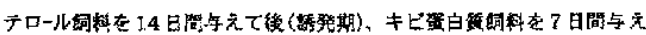

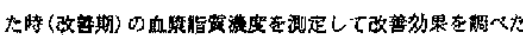

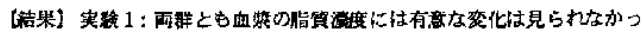

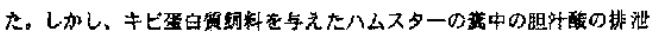

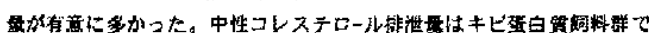

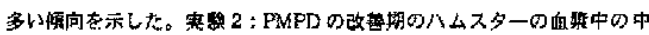

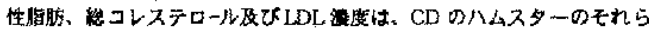

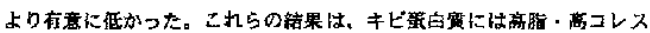

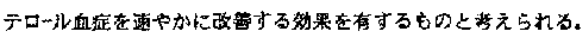

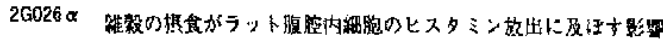

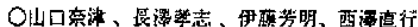
(岩手大典・店生)

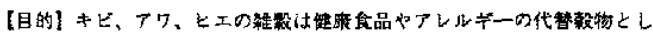

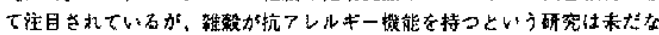

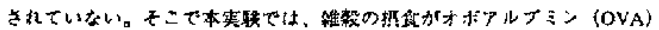

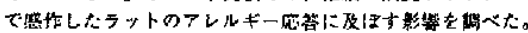

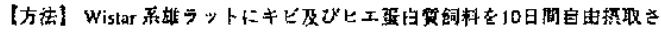

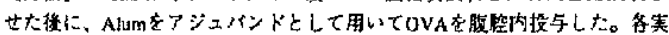

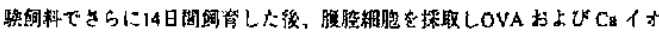

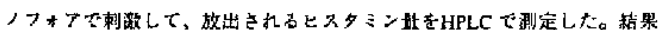

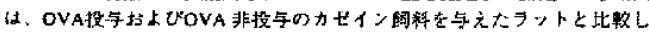

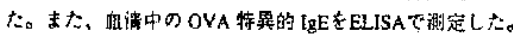

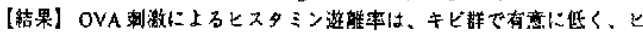

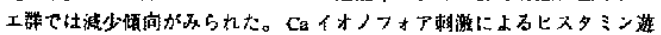

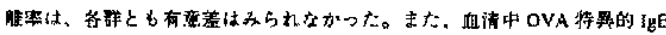

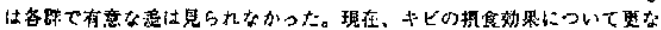

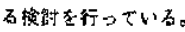

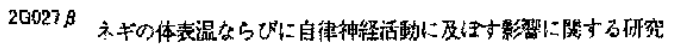
O井上尚应、日比野岳、仗不旁

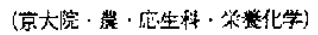

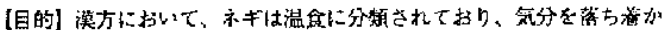

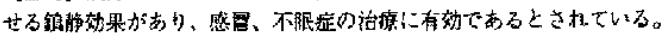

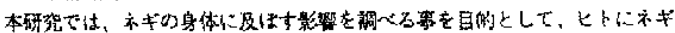

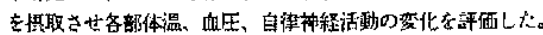

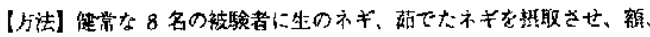

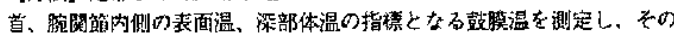

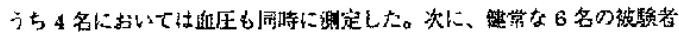

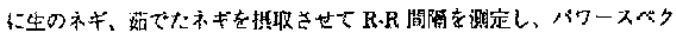

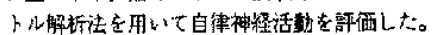

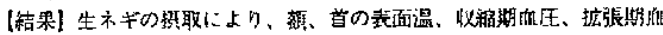

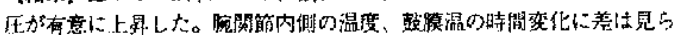
れなかった。また、生の神の拱取直後において、し拍数、主に交感神

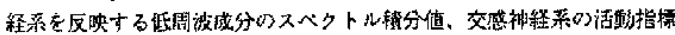

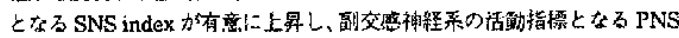

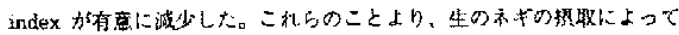

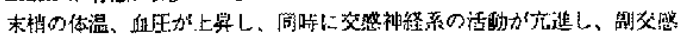

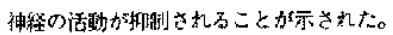

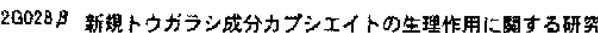

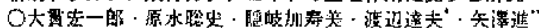

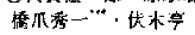

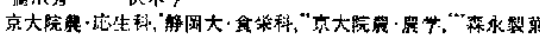

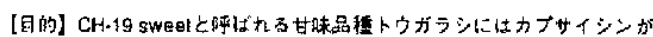

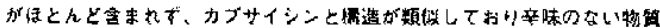

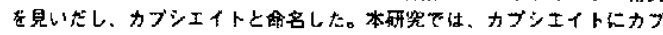

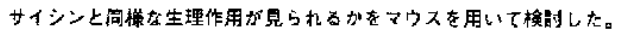

【方洼】1)カブシエイト段与纪よるマウスの体温変化；マウス江小型

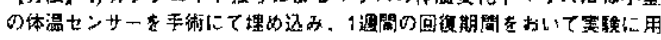
いた。力プサィシン、カブシエイトまたはコシトロールの海溷をマウスに

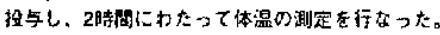

2)カブシエイト長期投与の影譬：カブサイシン、カブシエイト，またつ

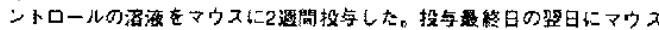

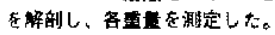

【䋊果】1)カプシエイトを投与したマゥスはカブサイシンを投与したマ

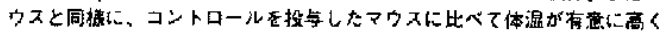
なった。カブシエイトはカブサイジと周掽に体熟應生をて進させること t西渡台机た。

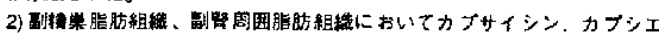

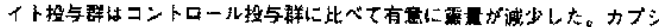

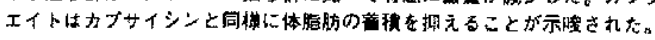




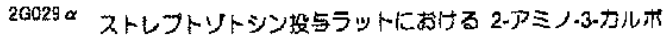

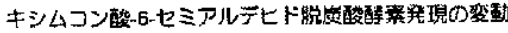

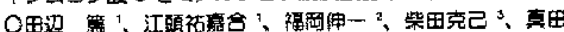

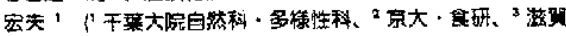
県大 $\cdot$ 生活文化)

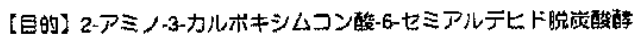

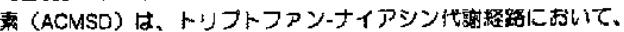

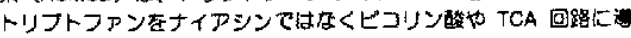

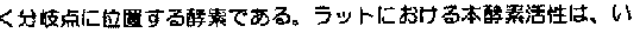

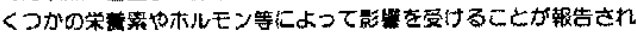

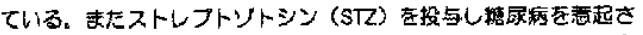
せたラットにおいても活性が上罳するか、, 今回 ACMSD mANA の篮 動について compelitive RT-PCR 法で梌討した.

(方法と結果) 10 週粭 Wistar

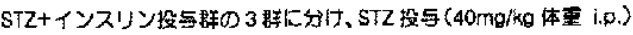
4 日後にインスリン投与 (4units/day s.c.) を閳始し、更に 10 日間

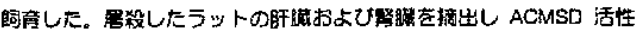

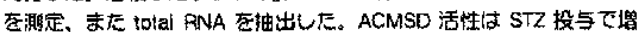
加し、この管加はインスリン投与によって和制された。抽出した total RNA は, DNA competitor 荌用UE competitive RT-PCR 法に供L。 ACMSD MRNA を比较梌豍した。

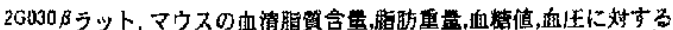

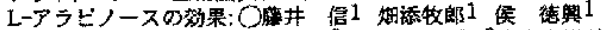

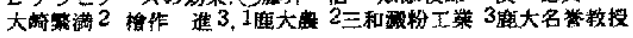

1. 目的: L-アラヒノース(以下Ara)は敖類なとのへミセルロ一スの 主成分であり、小渴スクラーゼを特罢的に阻客するのでスクロース似

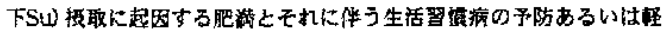

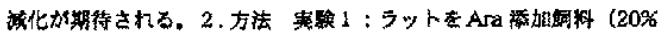

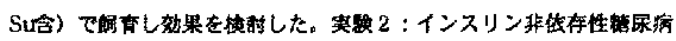
モデル KK-Ay マウスを用い，血榙值の变化を测定した。実雅 3 : 自

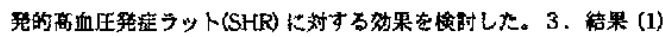

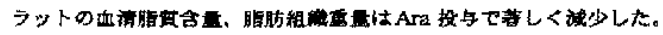

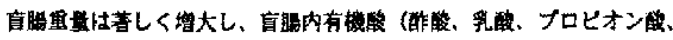
コハク酸など）新量も大幅に增加した。(2) 高血糖マウスKK-Ayは

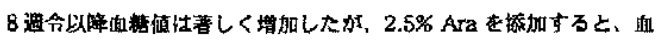

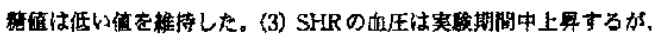

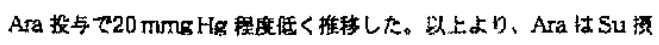

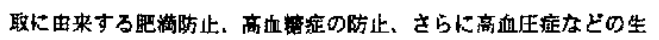
活習饭痛の予防・性旗化に有效であることが示された。

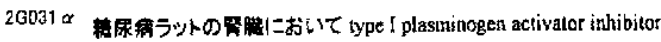
(PAI-3) 笔現が墙強する

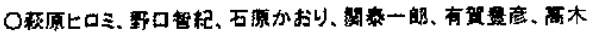

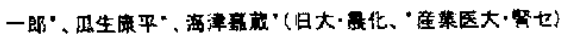

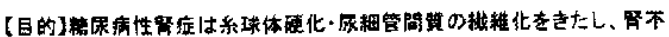

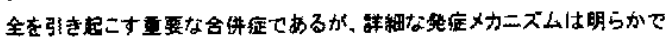

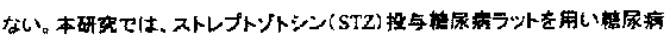

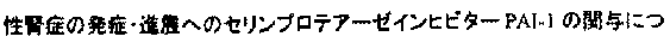

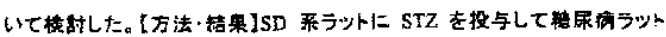

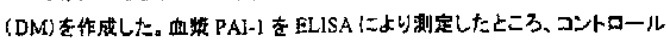

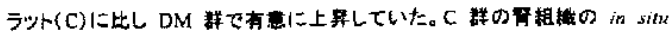

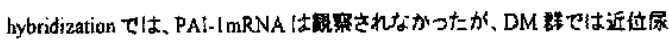

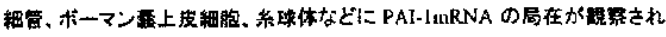

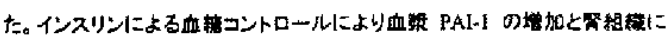

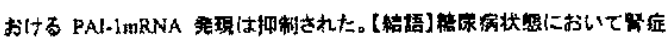

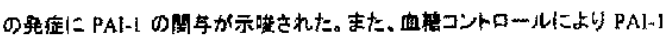
の然现が少することが明らかとなった。

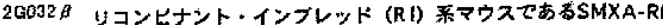

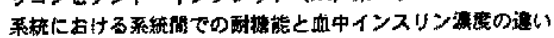

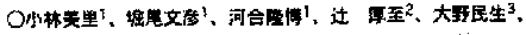

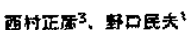

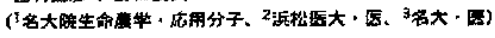

(目的) 5M/系とA/萧マワス加ら作出したリコンヒナント・インフレット

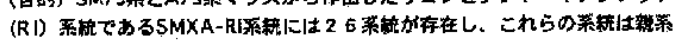

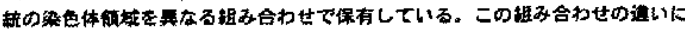

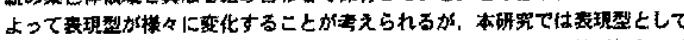

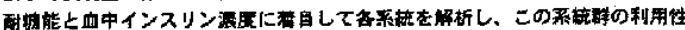

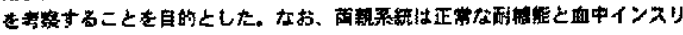
次原示寺.

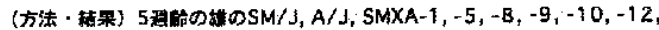

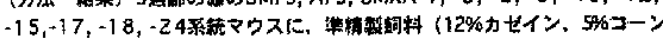

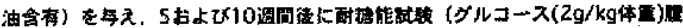

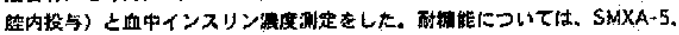

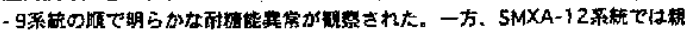

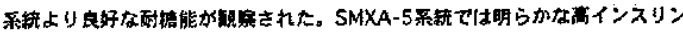

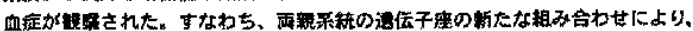

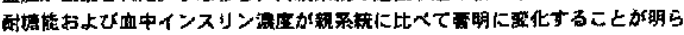

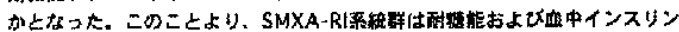

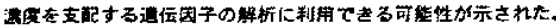

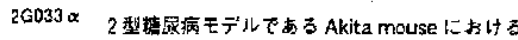

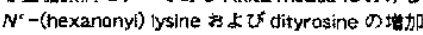

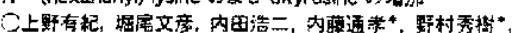

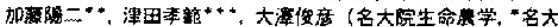

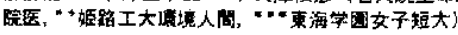

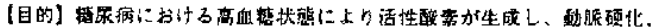

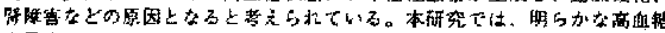

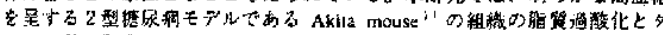

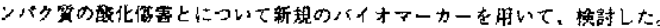

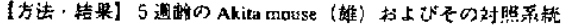

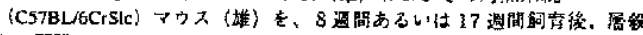

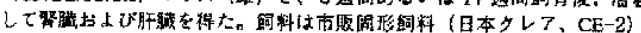

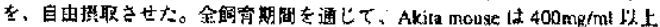

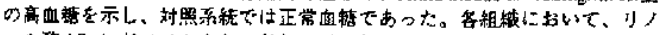

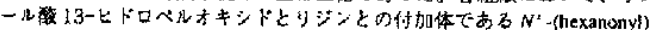

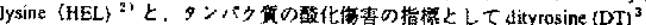

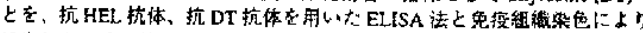

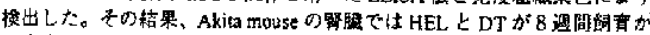

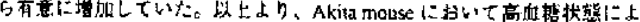

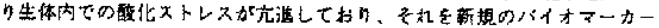

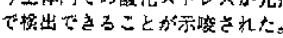

1)Yoshioka et al. (1997) Diaberes $46: 887-894$ 2)Kato el al. (1999) J. Bint. Chem. 274:20406-20414 3) Kato et al. (1998) FERS Lem 439: 231-234

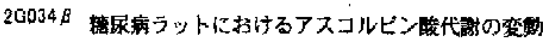

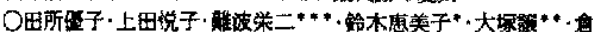

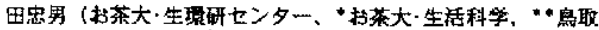

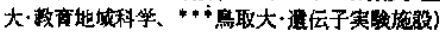

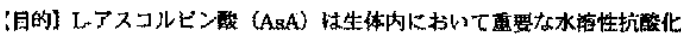

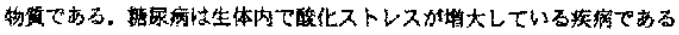

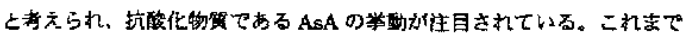

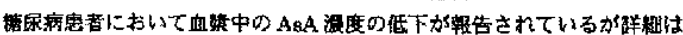

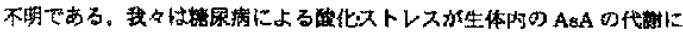

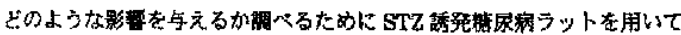

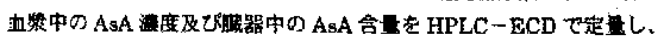

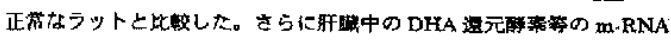
贯を competitive RT.PCR 法によって湘定した。

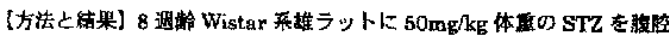

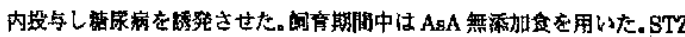

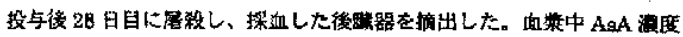

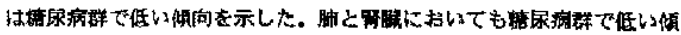

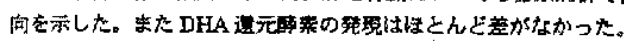




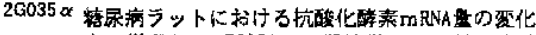

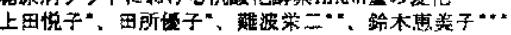

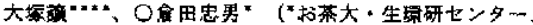

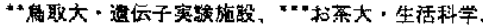
$* * *$ 第取大・数育地城科学

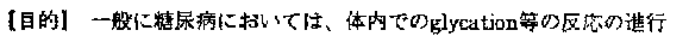

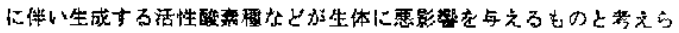

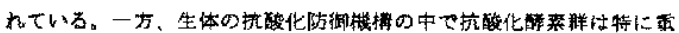

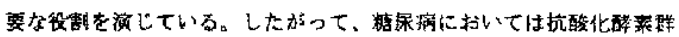

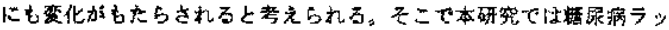

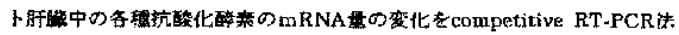
に上って㹸定した。

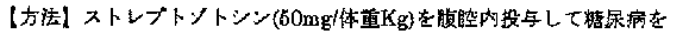

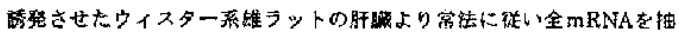

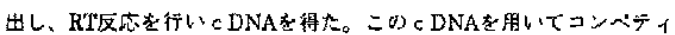
ターを作製し、competitive PCR法によりmRNAt定した。

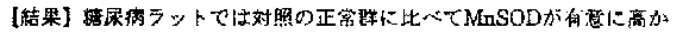
ったが、Pいダルタチオンバルオキシダーぜやカタラーぜには有意羔が 幅められなかった。

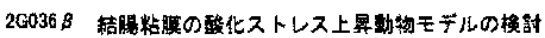

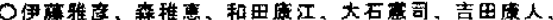

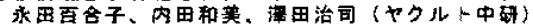

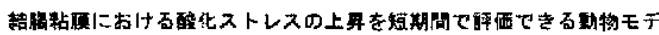

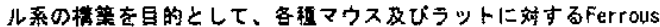

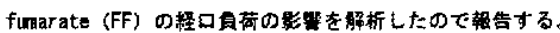
く方法〉物はBALB/cマウス、C57BLマウス、SOラット及じWistar

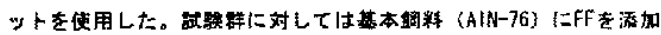

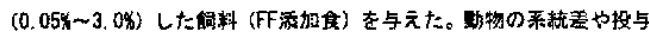

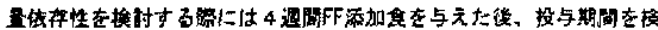

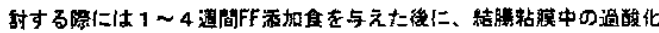

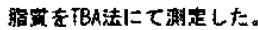

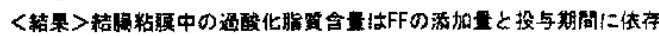

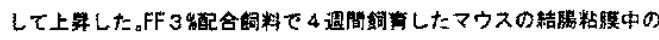

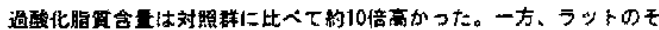

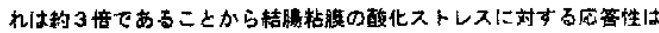

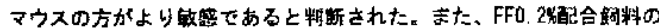

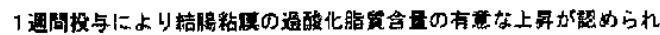

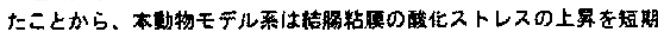

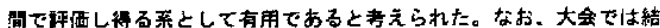

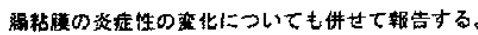

$2 \mathrm{G037} \alpha$

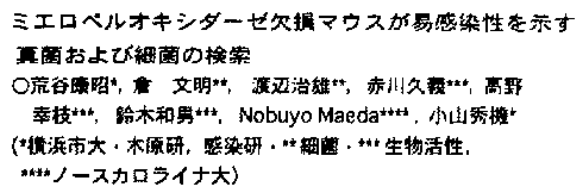

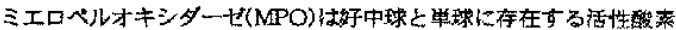

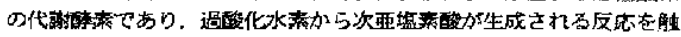

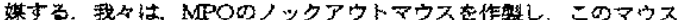
が力ンジ多国（C.albicans）に齐して著しい易感染性を示すことを

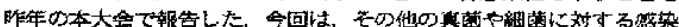

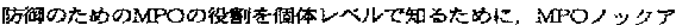

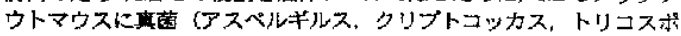

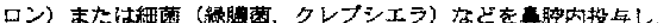

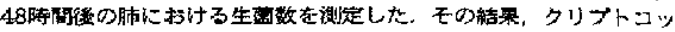

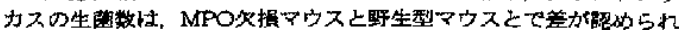

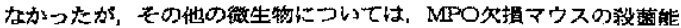

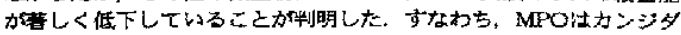

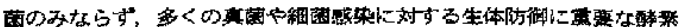
であることが明らかしなった

唒 : Aratani,Y.et al. Infect.Itrmun, 67,1828 (1999)

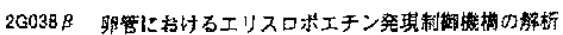

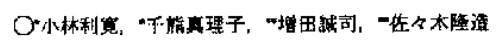

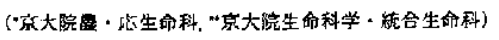

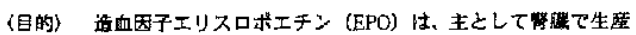

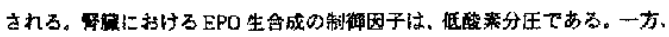

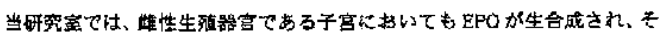

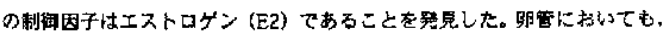

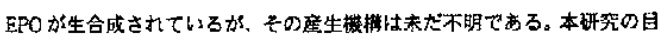

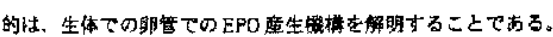

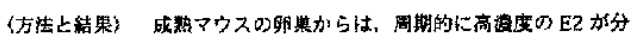

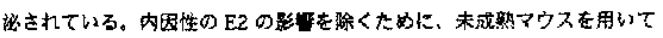

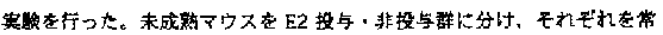

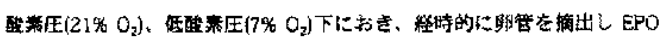

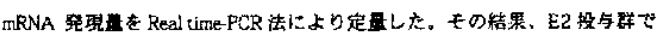

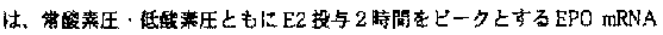

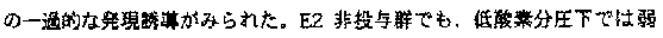

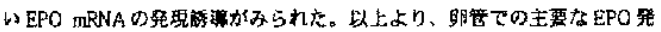

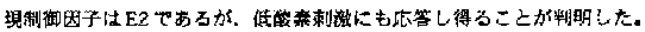

$2 \mathrm{G039} \alpha$ mRNA分解制街因子AUH1のラット等㻤せのエストロゲンによる

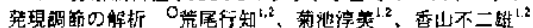
( ${ }^{1}$ 自治压太・医・保涟科学、 ${ }^{2}$ CREST,IST)

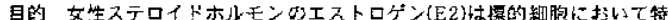

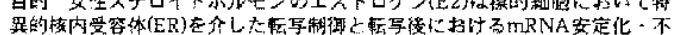

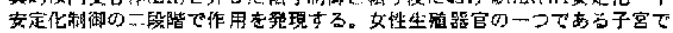

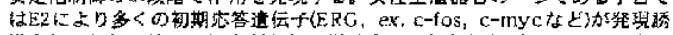

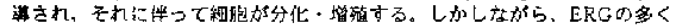

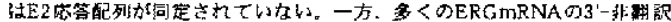

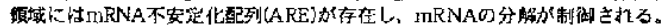

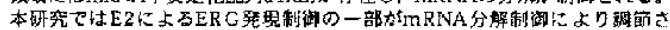

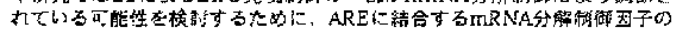

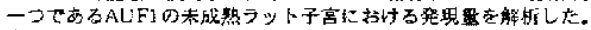

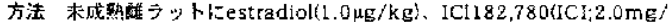

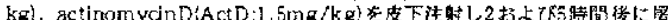

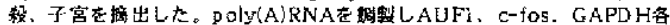

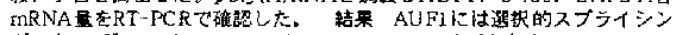
グにより4榓のアイソフォーL

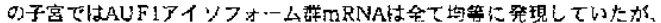

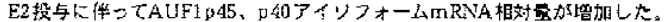

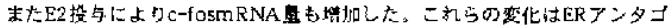

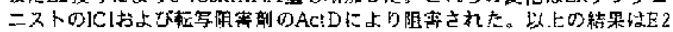

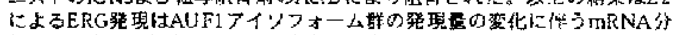

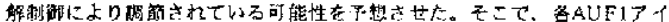

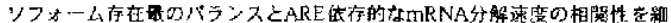
胞を用いたin vitromRNA分解解析系で接的中である。

20040B ラット再生肝におおるPtotein B23 の無現について

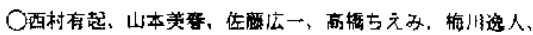

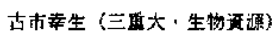

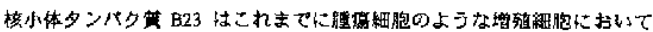

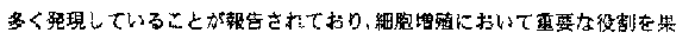

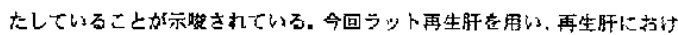

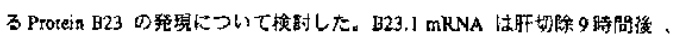

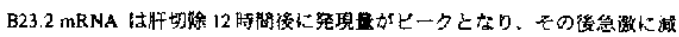
少した。同時に㴰定し底 DNA polymerase $\alpha$ 活性の結果より、B23.1、B23.2上

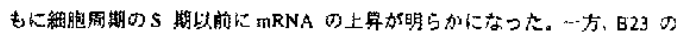

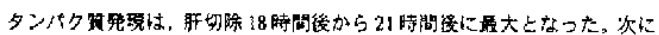

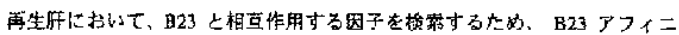

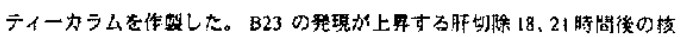
地出物を、B23 アフィニティーカラムに供し KC! で洛出を行った。その結

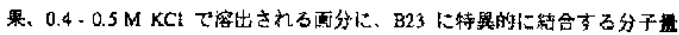

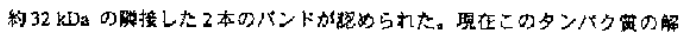
析を行っている。 


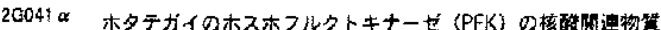

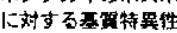

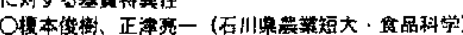

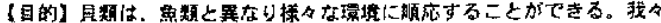

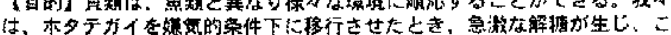

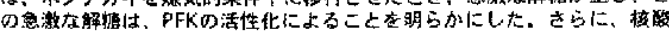

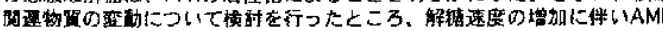

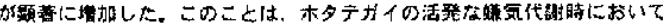

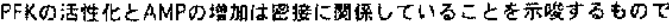

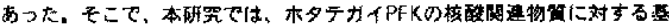

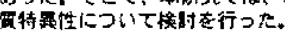

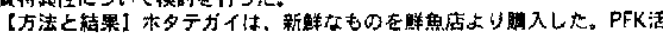

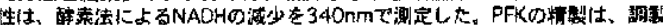
した相啸素源に対し、各程クロマトグラフィーを用いて行った。まず、精

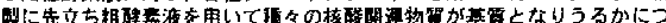

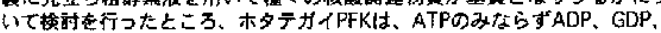

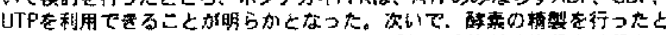

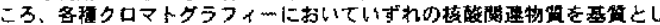

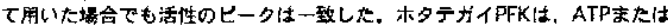

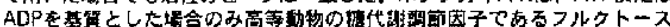

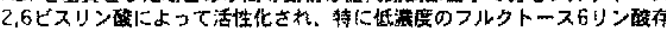

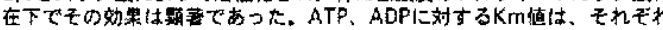

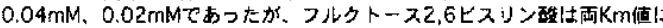

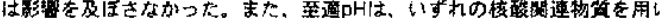

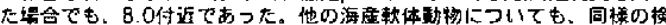
敦を行去。

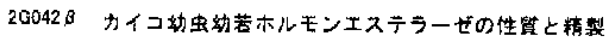

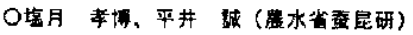

【目的】昆虫の脱皮・变憼に係わる纳舌ホルモン (JH) の浱度は、

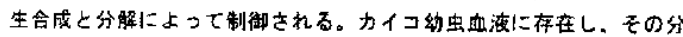

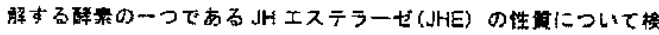

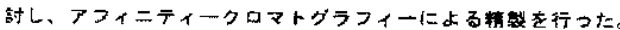
【方法・結果】カルボキシルエステラーゼの筈性測定に用いられる基 留〈4-nitrophenyl acetate, 1-naphthyl acetate〉とJHE 活性㴬定用の 巷 (S-methyl 1-heptythioacetothioate, トリキウムラベル」H III)

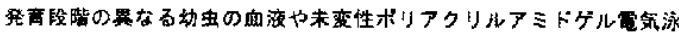

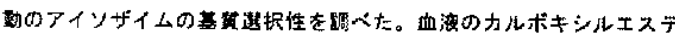

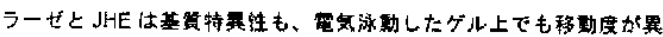

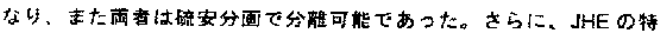
翼的龨䈉削、3-octylthio-1,1,1-trifluoropropanone の部分满造をリガン

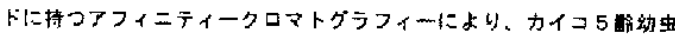
血浚加ら筒便にJHEの維慗が可能であった。一方、昆蚆 JHEの

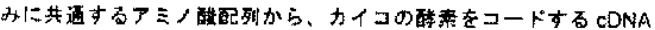
のクローニンダを䧕みた。

$20043 \alpha$

$$
\begin{aligned}
& \text { サメ|型コラーゲンの細胞培娄 } \\
& \text { およびザイモグラフィー基的への応用 }
\end{aligned}
$$

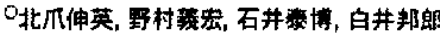

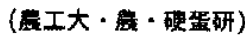

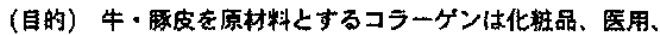

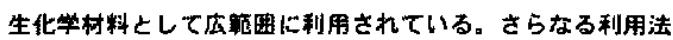

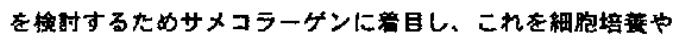
ザイモクラフィーの基筫としての有用性について梌钨した。 （方法）コラーゲンコート、ゲル上,ゲル中に線維芽細䶼を

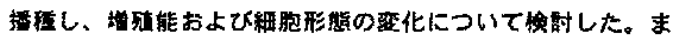

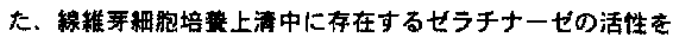
サメせラチンおょびコラーダンザイモクララフィーで椮封した。 （結果）コラーゲンゲル上での細胞培羑の結果、サメの方が フタコラーゲンに比へ增殖能か低かった。サメぜチンザイ モの結果、分子量70および 140kDa付近にバンドが踉められ た。サメコラーゲンでのザイモグラフィーが可能であった。

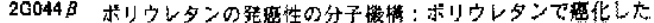

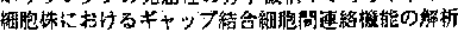

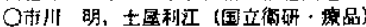

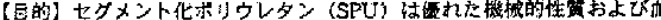

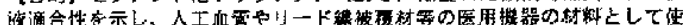
用されている。しかし、SPUをラット皮下に埋䅦才无と理植部偣に20 30\%

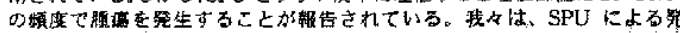

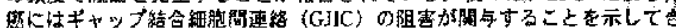

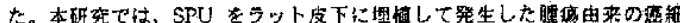

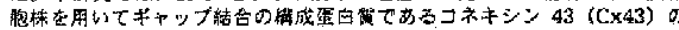

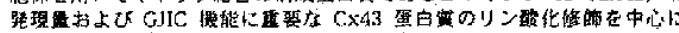

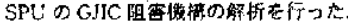

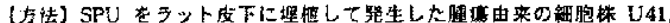

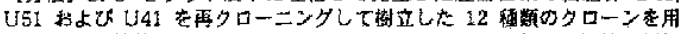

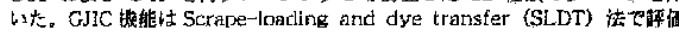

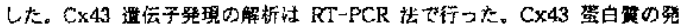

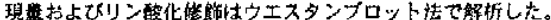

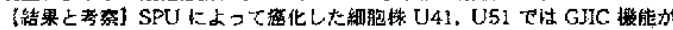

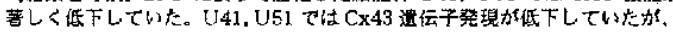

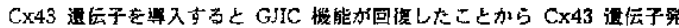

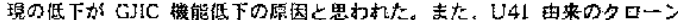

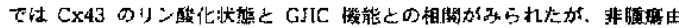

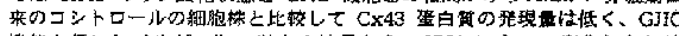

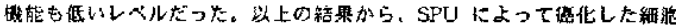

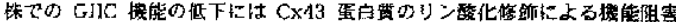

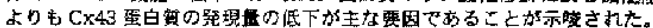

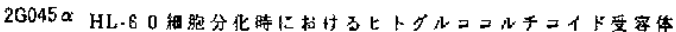

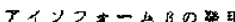

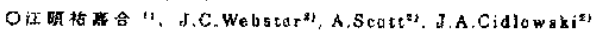
('千䨤大・生物生座, 'N NIH. NJEHS)

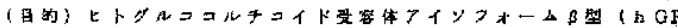

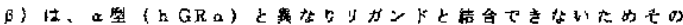

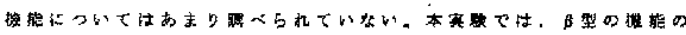

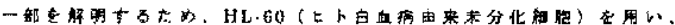

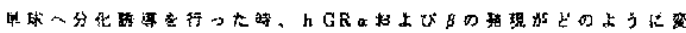
北古当加彼封した。

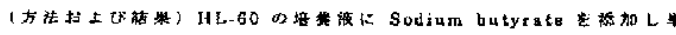

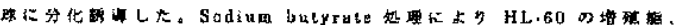

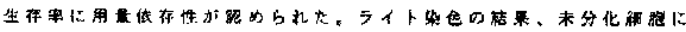

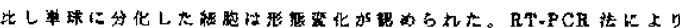

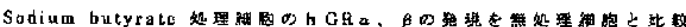

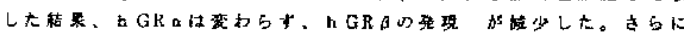

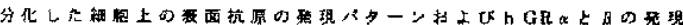

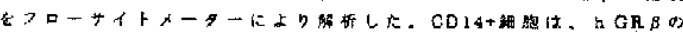

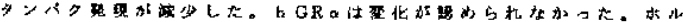

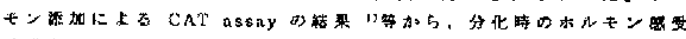

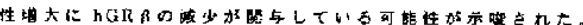

1) Oakley.R.H.ct al.J.Bial.Cham.,271,9550-9559(1996)

20046 B 上羊膜のエリスロポエチン生産に笴与する因子の检䒺

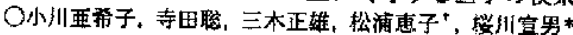

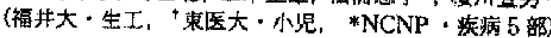

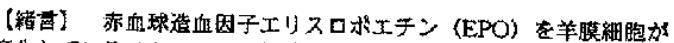
痤生していること、そして低破䅈分圧(この象件て EPO 㖒生が增 強されることが知られている)下でも羊膜の FPO 壁生加增強され ないこと、昨度大会で報告した。邲想ホルモンである エストラシオール(エストロゲン) 加子宫内膜細胞の EPO 廉生

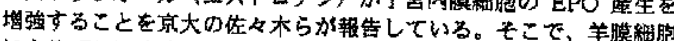
による EPO 生産を漱御する因子を明らかにするために、工ストロ

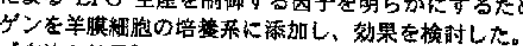

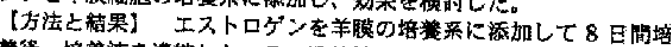

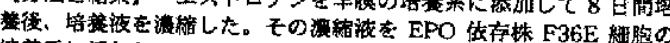

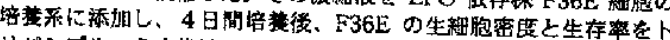

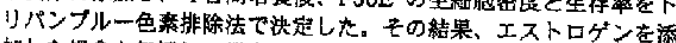

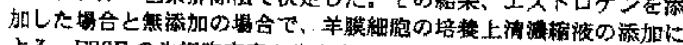
上る，F36E の生細胞密度亡生存案の上异は同程宽であった。

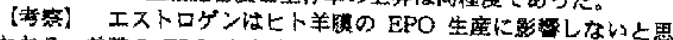

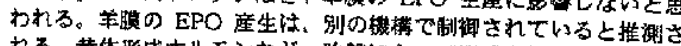
れる。黄体形成ホルモンなど、胎盤によって形成される䛧のホルモ

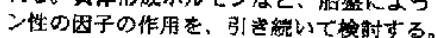


$20047 \%$

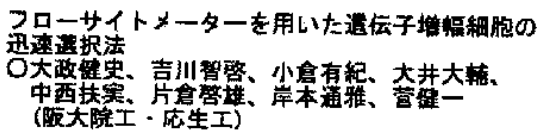

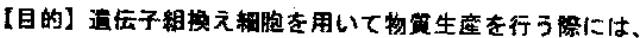

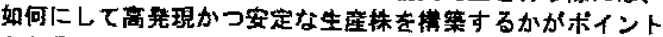

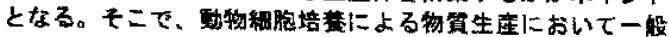

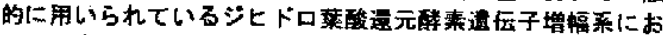
いて、高発現かつ安定な耕胞株のフローサイトメーターを用 いた迅速筫杓法について模封した。

【方法及び桔果】宿主細胞としてCHO DG4細盷株をを用い、

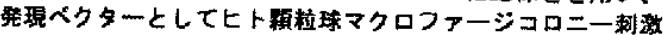
图子 (hGH-CSF) を組次込んだpSV2-dhfr/hGM-CSF" を用いた。

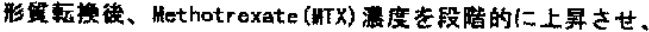

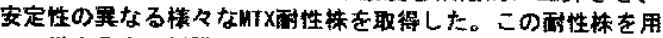

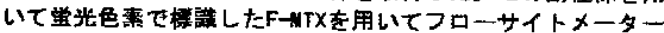

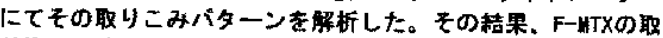
り込みの違いによって安定かつ高発現な細胞を選択できるこ 上が靸った。

1)T.Yoshikawa et al., Cytotechnology (accepted)(2000)

$26048 \mathrm{~B}$

不死化ヒトB耦胞による低アレルゲン化ぜラチン のアレルゲン性評価

○新本洋士，山岸堅治，木村传之。

鈴杰雅博，酒井原夫

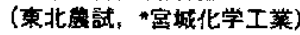

【目的】ゼラチンアレルキーに対する予眆接種副反充の回

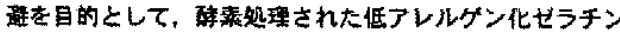
か開無されている。この呧アレルケン化ゼラチンは费者血 清徂Eとの反度性がほ上んどない事が証明されている。本研 究では，演着らか近年作出した不死化ヒトB細跑ライブラ

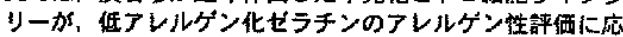
用可能か否かを尌した。

【方法およひ結果】不死化ヒト日种胞ライフラリーを榙索

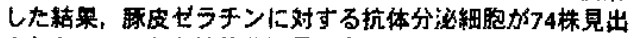
された。このうち抗体分泌量の多いものについて抗体のク ラスを決定したところ，いずれも四のラスであった。いく

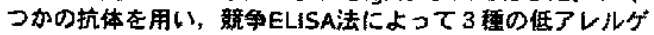
ン化ぜラチンのアレルゲン性を測定した。その結果，低ア レルゲン化ぜラチンは抗体の貱菠ラチンに対する結合 を、まったく阻害することができず，アレルゲンとしての 性䀠をとんど持たないと推定された。

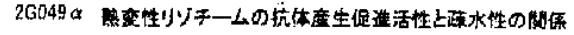

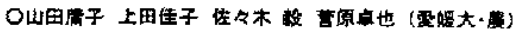

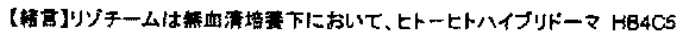

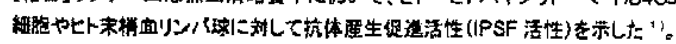

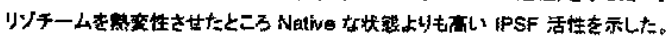

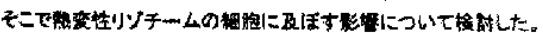

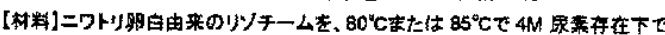

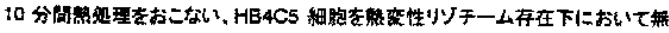

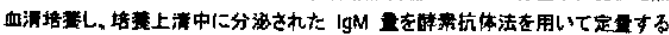

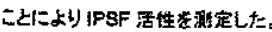

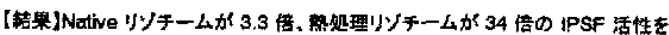

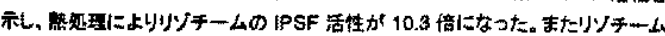

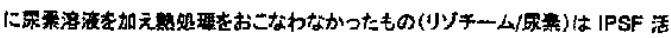

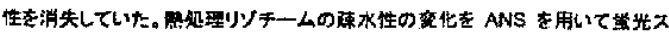

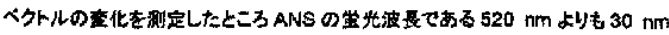

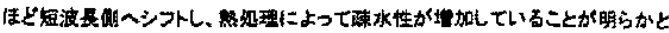

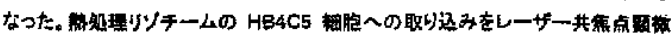

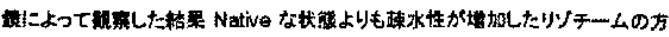

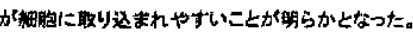

"F. Murakami ex al, Cytotechnalogy 24, 177-182, 1997.

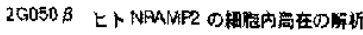

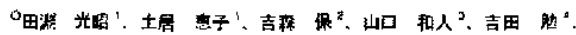

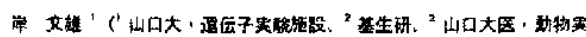

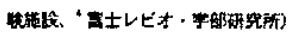

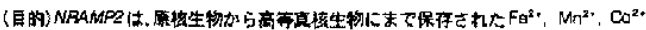

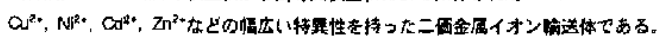

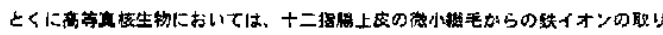

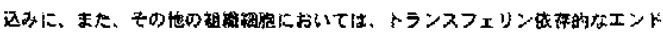

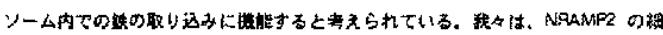

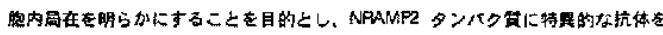

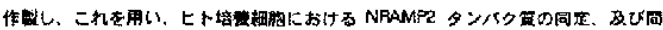

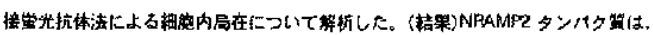

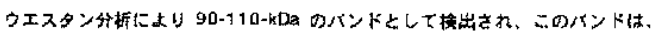

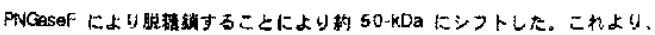

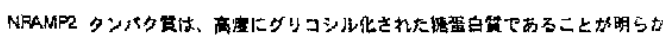

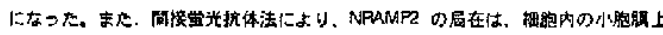

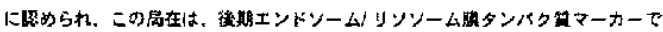

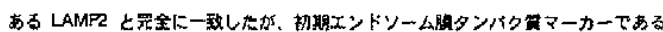

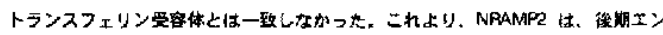
ドソームリソソームに后在すること奔明らかにした。

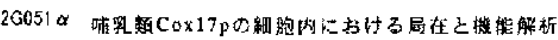

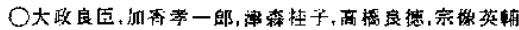
(钺波大·底生化)

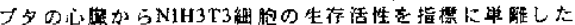

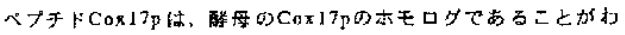

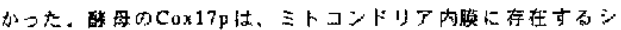

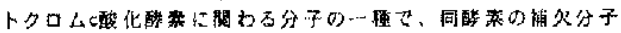

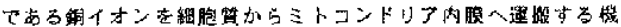

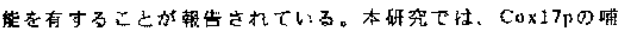

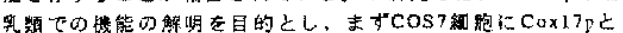

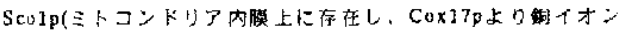

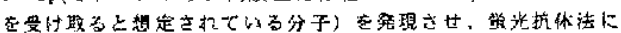

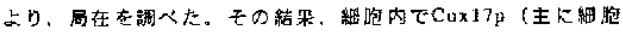

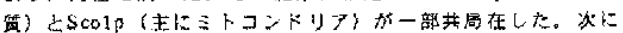

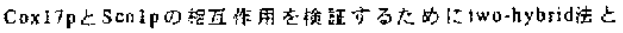

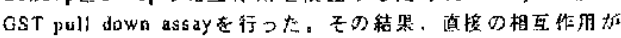

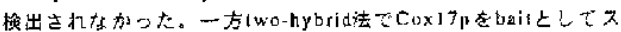

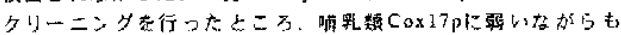

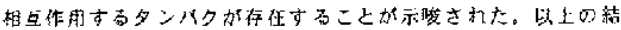

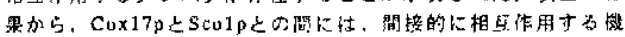

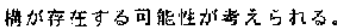

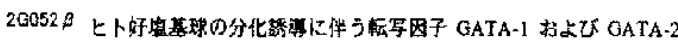
の菫現增大

O原立花宏文、山田耕路（九大院生丵・化工）

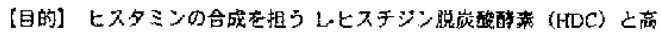

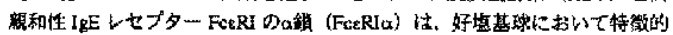

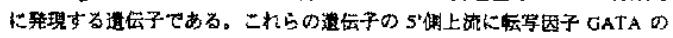
絬合确位が存在することから、その発現には GATA の閶与が予想される。

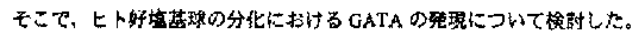

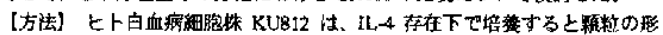

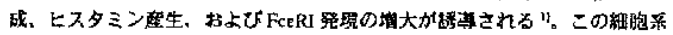
を用い, HDC、FCERla、さらに付 GATA 枟军因尒である GATA-h、GATA-

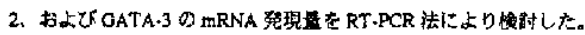

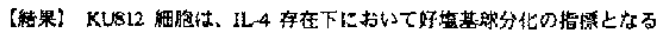

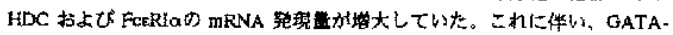

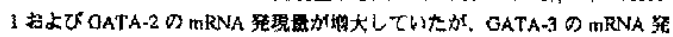

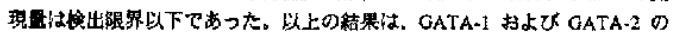

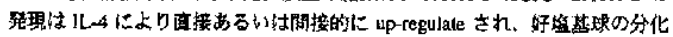
に鬥与ちることを示投している。

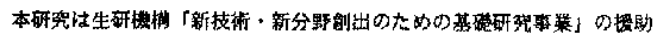
ヒよるものでる。

1) Hara ef al. Biochem. Bjophys. Res. Commun. 247, 542-548 (1998) 
$2 \mathrm{G} 053 \alpha$ Functional changes of human LOX-l in ligand bindiag by mulagenesis XH Shi, S Nimi, S Machids National Food Research Insliture, Minisry of Agriculturc, Forests and Fisines

OBJECT Lectinlike modified LDL receptor (LOX-1) is a recently identified membrane protein. We constnucted several mutagenesis clones of human LOX. It explore the selationstip between its straclare and function. METHOD The mutant canstructs were generaled by the sile-directed mutagenesis using PCR and cloned into pCDNA3.1 expression vector. The protzin function was evaluated by the binting of Dil labelled acetylaledLDL(AcLDL), one of ligands of LOX-L, with transiert transfected COS-7 using fluorescent microscope.

RESULTS Within complimeatary recognition domain (CRD), residues 143273. the point mutation of six Cys at position 144, 155, 172, 243,256, 264 to Ser deprived of the ligand binding actixity, suggesting all of Cys in this domain is necessary for the protein fuaction. Five deletion mutants, residues 167-171, 178-185, 207-213, 226-231, and 266-273, also failed to bind AcLDL. Within tow of those deletion regions, replacement of Arg208 and Arg209 with Asn significantly decreased AcLDL binding, whereas seplacement of A.rg229 and Arg231 with Asn combined with change His226 to Gin deprived of ligand binding abilisy. For "Neck domain", residses 61-142, a truncated clone of residues 95-142 showed that is was significantly decreased in AcLDL binding. Taken together, CRD domain is essential for the function of LOX-1. howaver the erucial ligand recognatien motif of this prolein as well 2.5 the sole of "Neck doutsin" on the interaction of ligand and receptor need to be clarified further.

2G054 B ERー6 0ブロテアーゼとB i P間相互作用の船䉼

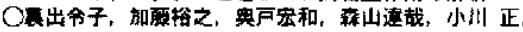

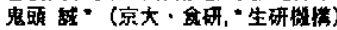

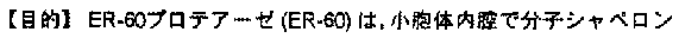
日iPと結命することを明らかにしてきた.これらの分子間相亘作用の分

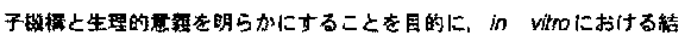
合および解能を速度路的に解析した。

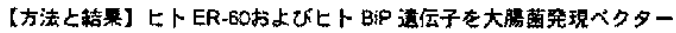

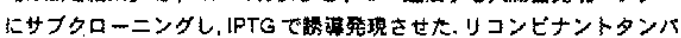
ク独はそれそれ常法て純化した、リコンピナントBiP ATP結合能を有

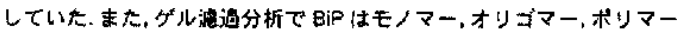

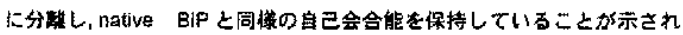
た. BiFの基为モデルとして unfolded $\boldsymbol{\alpha}$-lactalbumin をセンサーチップ CM5にカッブリングさせ，8i户 モ/マーとの相互作用を BIACORE 2000

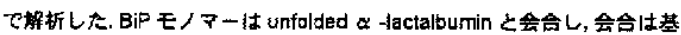

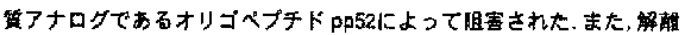
はATPによって促造された、センサーチッフ上の ER-60亡 BiPモノマ

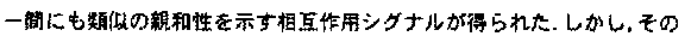

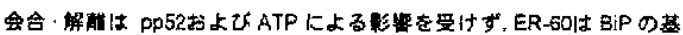

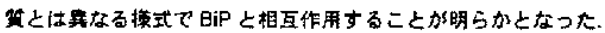

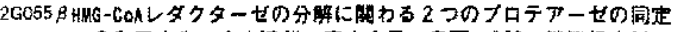

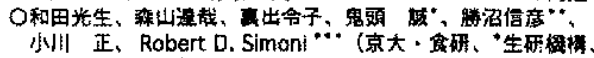

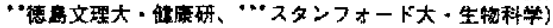

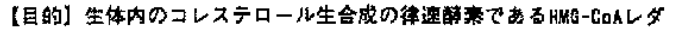
タターゼ(HMGR)は絊腹内コレステロールレヘルが上昇をるとその分解が

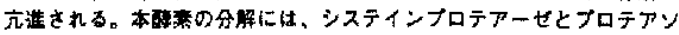

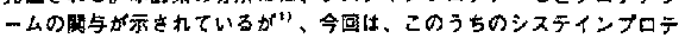

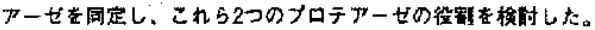

【方法】圳肘の鲜は、沉体を用いたウエスタンブロッティングによっ

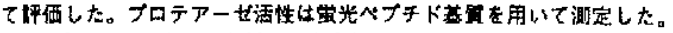

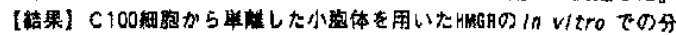

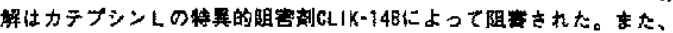

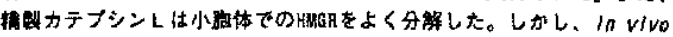

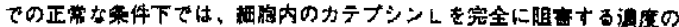

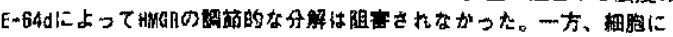

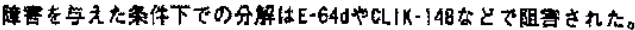

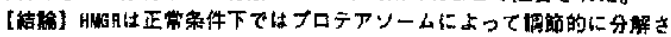

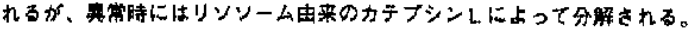
いずれの为合もステロール処理により代解が茫造されることからステロ

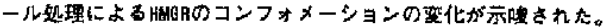

1) Moriyama T.et af (1998) , J. Biol. Chem., 273, 22037.

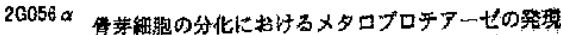
○水谷昭文、杉山育子、久野江里子、昖水幸子、越规弘

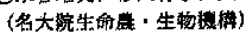

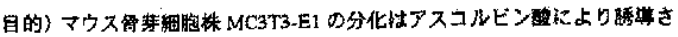
そる。当研究空では、本粗盷㧣の分化に汼け tissue inhibitor of

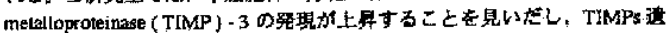

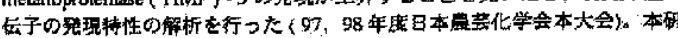

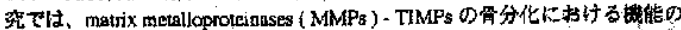

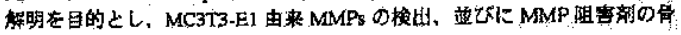

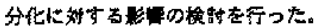

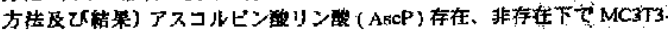
E1 を㛺宾後、 conditioned mediun ( CM) を国制 L, gelatin zymography $k$

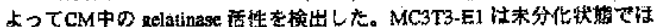

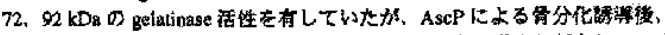
$72 \mathrm{kDa}$ 活性の上界が見られ、さらに、分化の初期段陸より新たに $64 \mathrm{kDa}$

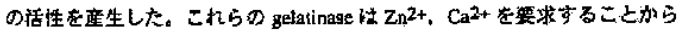
metalloproteinase であり、分子量から MMP-2、9と考えられた。 MMP陮客 剂の存在下では、分化マーカーである alkaline phosphatase 活珄の発琵が斻 制された。以上から骨形成時の MMP の閶与が示坡された。現在、分化特，

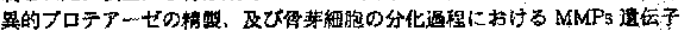

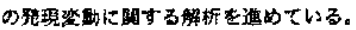

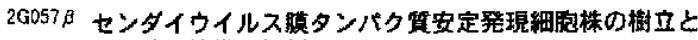

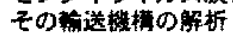
何部罚久。山下暂郎、O平 秀暗

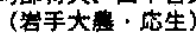

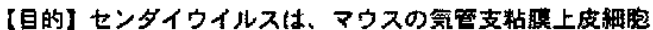

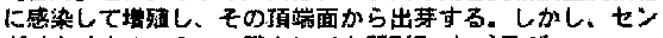

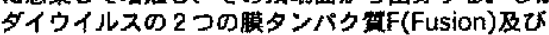
HN(Hemagglutinin-neuraminidase)か頂滞画に䡫渼される

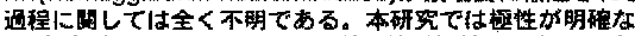
MDCK細胞を用い、两ダンパク再の輸道植性を明らかにするこ とを目的とした。

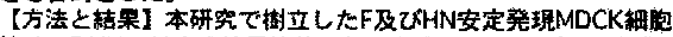
楼は、F，HNに対する特異抭体を解いたウエスタンブロット及

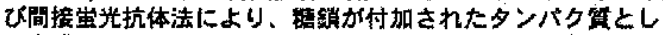
て合成されていること、細胞表面末て粭送されていることか

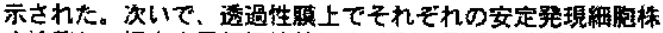

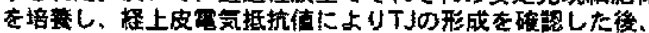

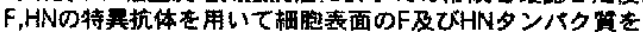

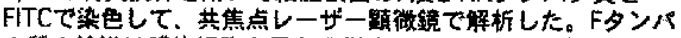

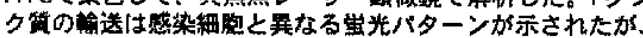

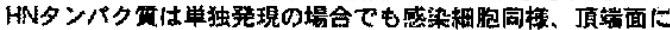
船送されることが示された。

$2 \mathrm{G058} \alpha$

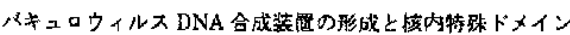

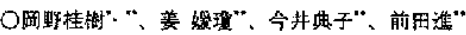

(“秋田県草大·生物祭源、“埋研・分子昆虫)

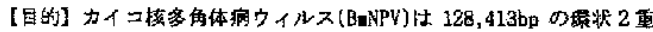
鉷 DNAをグノムとして有するバキュロウィルスである。本研究ては，

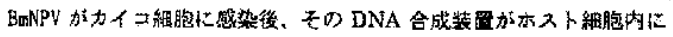
どのようによて形成さ扎るのかを琱べた。

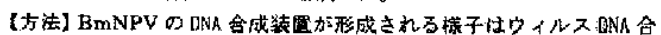

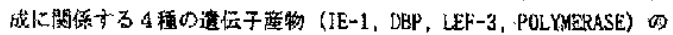

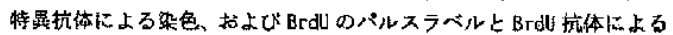
新规 DNA 合成部位の染色を組み拿わせることて行った。

【結果】レーザー顆微鏡たよって、その分布と形成㶽程を正確に追跡

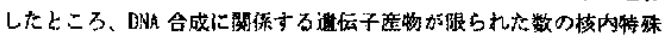

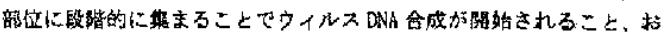

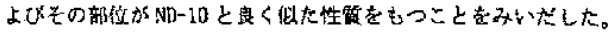

<文郦〉 Okano, K., Mikhailov, M.V. and Maeda, S. (1999). Journal of Virology 73, 110-119.

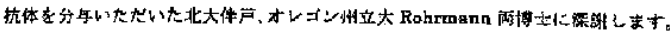


$26059 B$

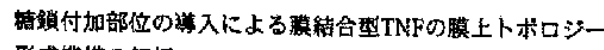
形成機檴の舿析

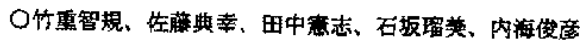

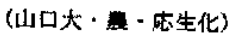

[目的] 膜結合型TNF(Pro-TNF)の膜局在化機䋨の解明を目的としたこれ

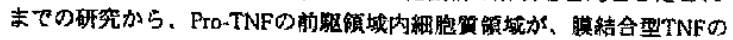
䝢上トボロジー形成に必須であることを示した。本研究では、このこ

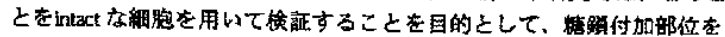

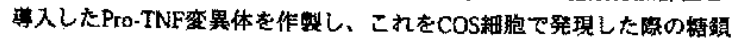

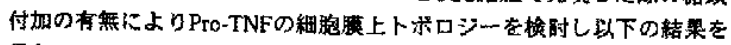
得た.

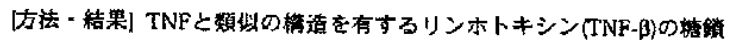
估加配列をProーTNEの対虑する領域に售入した坐異体を site-directed muta-

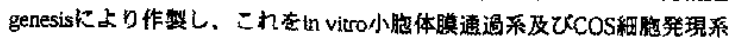

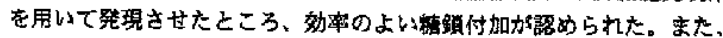

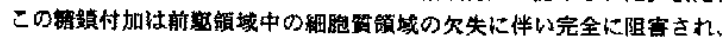

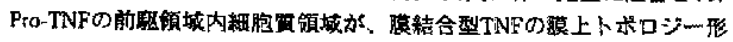
成に必須でることが找盷レベルで確珞された。

$2 \mathrm{G060B}$

䠑結合型TNF(Pro-TNF) の㬺上トボロジー形成における

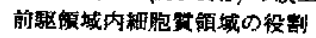

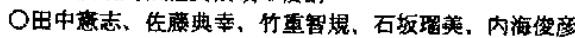

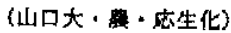

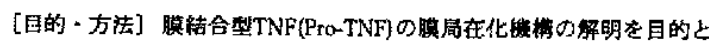

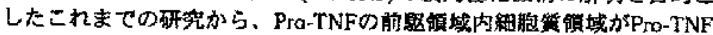
のI塑の䀧上トホホロジー形成に開与していることを示した。本研究て

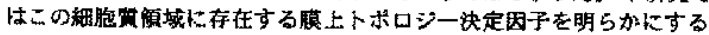

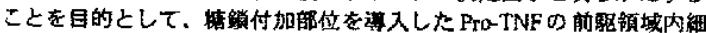

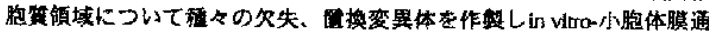

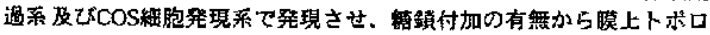
ジーを模矿し以下の結果を得た。

[結果] 綎胞䁈領域を全て欠失させたPro-TNF変異体においては、I型

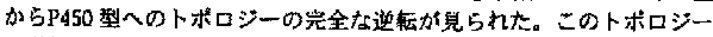

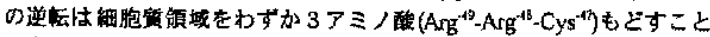

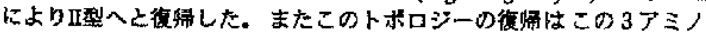

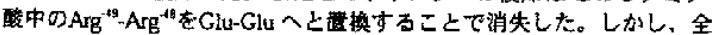

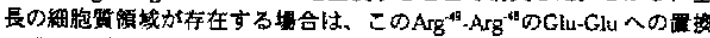

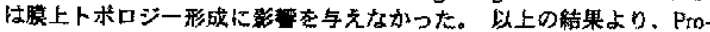

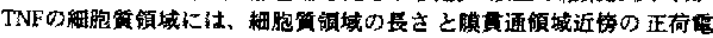
アミノ破という2つのトポロジー決定因子尔存在することが示さ扎た。

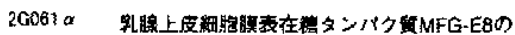

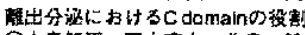

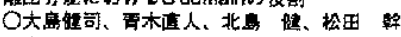

(名大院生侖算学・応用生命)

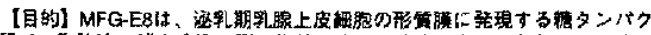

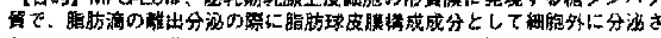

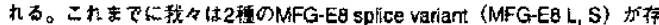

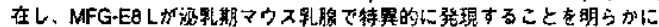

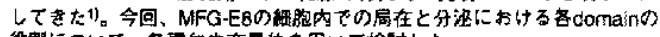

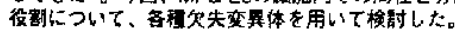

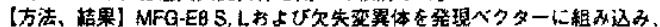

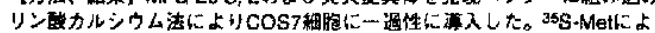

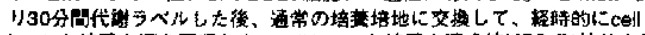
lysale

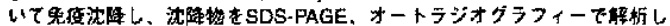

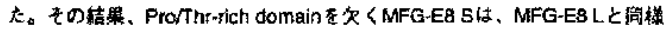

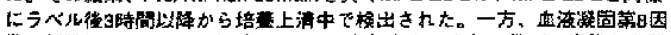

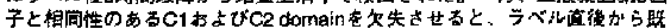

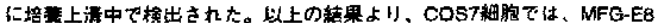

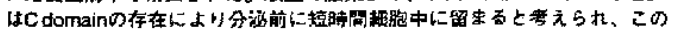

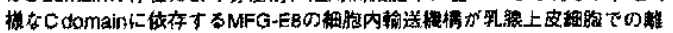

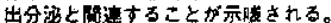

1) Biocham. Biophys. Aes. Commun. 254, 522-528, 1999
$20062 \alpha$

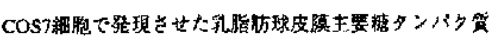
ゾチロフィンーーキンチンオキシターゼとの結合、多量体化 チロシンリン酸传一

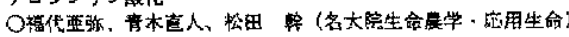

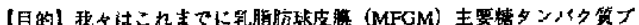

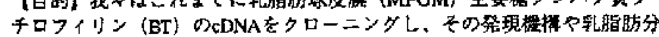

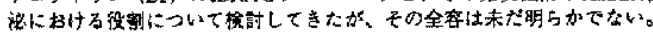

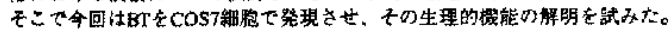

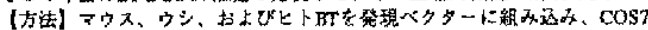

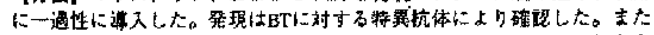

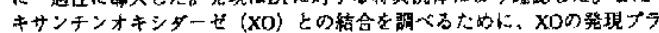

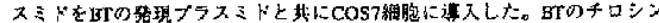
リン破化は抗ボロシンリン酸化抗体(PX20) を用いたウエスタンプロッ

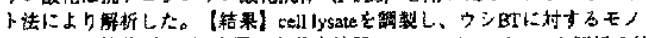

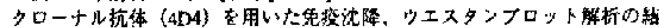

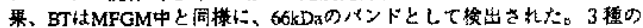

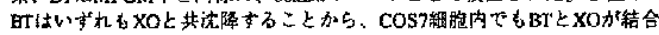

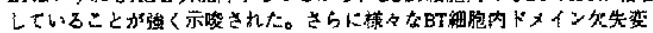

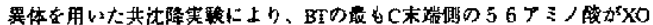

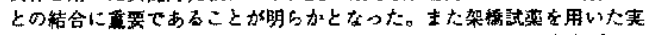

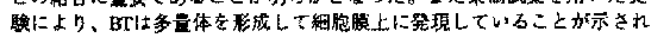

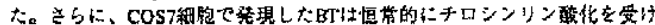
ていることる明らかとなった。現在りン睖化チロシン残基の同定とチロ

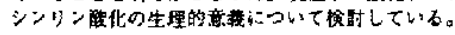

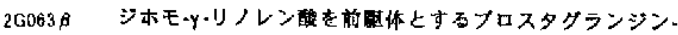

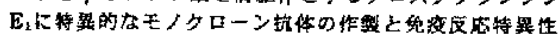

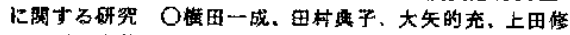

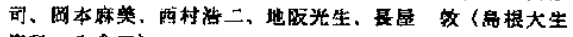
谟科-生会工)

シクロオキシゲナーゼ経路てつくられるプロスタグラジン(PG)

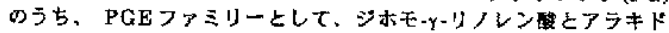

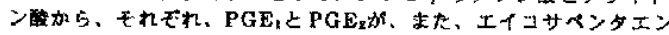
酷加

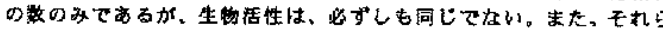

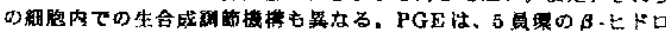
キシーエノレート中闌体を介してPGAやPGBへ变换され石ため、

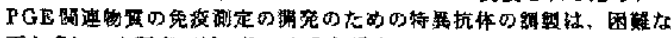

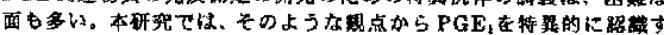

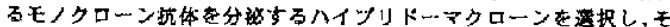

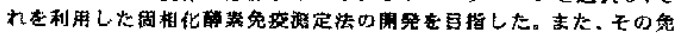

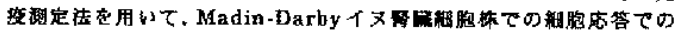

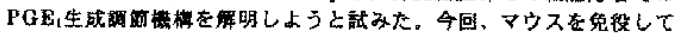

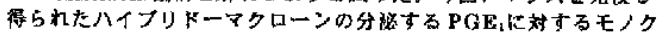

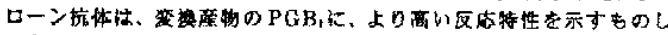

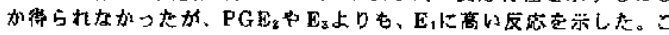

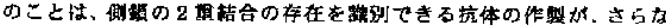

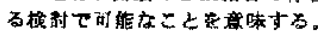

\author{
$20064 \alpha$ IL-1 加耧胞O tissue-5ype plasminogen activater (IPA)

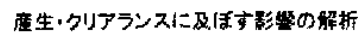

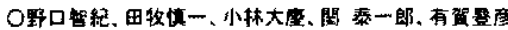 \\ (日大生算科・屡化)
}

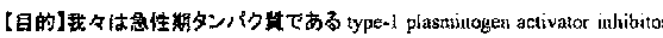

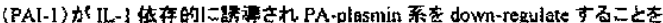

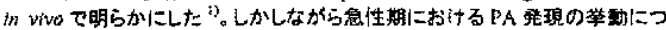

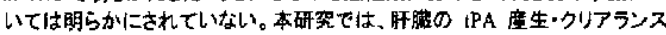

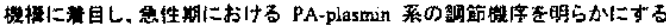

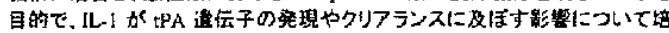

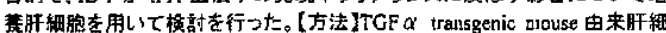
胞 AML12 を DMEM/HanF12 でコンフルエントまで培し、I-PA 英现に及

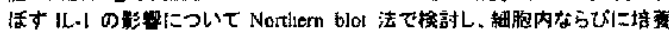

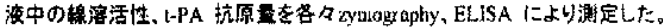

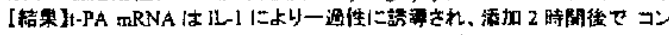

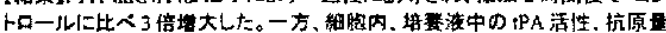

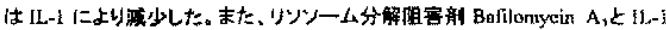

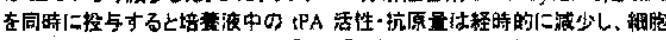

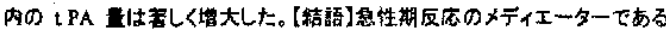

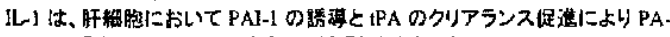
plasmin 系党 down-regulate することが明らかとなった

1) T. Seki, T. Noguchi el al, Americon J. Physiol, GI 277: G801-809, 1999. 